This manuscript has been submitted for publication in GSA BULLETIN. Please note that, despite having undergone peer-review, the manuscript has yet to be formally accepted for publication. Subsequent versions of this manuscript may have slightly different content. If accepted, the final version of this manuscript will be available via the 'Peer-reviewed Publication DOI' link on the right-hand side of this webpage. Please feel free to contact any of the authors.

August 7, 2020 


\title{
Cretaceous to Recent Net Continental Uplift from Paleobiological Data: Insights into Sub-Plate Support
}

\author{
Victoria M. Fernandes ${ }^{1}$ and Gareth G. Roberts ${ }^{1}$ \\ ${ }^{1}$ Department of Earth Science and Engineering, Imperial College London, South Kensington Campus, SW7 2AZ, UK. \\ Correspondence to: v.fernandes17@imperial.ac.uk, gareth.roberts@imperial.ac.uk.
}

\begin{abstract}
There are many geoscience problems for which constraining histories of uplift or subsidence of Earth's surface is of direct or indirect importance, for example reconstructing tectonics, mantle convection, geomorphology, sedimentary and chemical flux, biodiversity, glacio-eustasy and climate change. The least equivocal constraints on timing and amplitude of vertical motions on geological timescales come from the distribution of rock formed in shallow marine environments. However, obtaining enough observations at sufficiently large spatial and temporal scales $(\sim 100-10,000 \mathrm{~km}, \sim 1-100 \mathrm{Ma})$ to constrain histories of regional topographic evolution remains challenging. To address this issue we adapted modern inventories of paleobiological and paleoenvironmental data to generate a new compilation of $>24,000$ spot measurements of uplift on all continents and numerous ocean islands. Uncertainties associated with paleobathymetry, post-deposition compaction and glacio-eustasy are assessed. The compilation provides self-consistent, and, in places, high-resolution $(<100 \mathrm{~km}$ length-scale, $<1 \mathrm{Ma})$, measurements of Cretaceous to Recent (post-deposition) net uplift across significant tracts of most continents. To illustrate how the database can be used, records from western North America and eastern South America are combined with geophysical observations (e.g., free-air gravity, shear and Pn-wave tomography) and simple isostatic calculations to determine origins of topography. We explore how lithospheric thinning and mantle thermal anomalies may generate uplift of the observed wavelengths and amplitudes. The results emphasize the importance of large inventories of paleobiological data for understanding histories of tectonic and mantle convective processes, and consequently, landscapes, climate and the environment.
\end{abstract}

\section{INTRODUCTION}

Vertical motions of Earth's surface are used to inform almost all branches of the Earth Sciences. They are used to understand, for example, growth of mountain ranges, deep Earth rheology, natural hazards, histories of mantle convection, glacio-eustasy and sedimentary basin formation (e.g., Ziegler et al., 1985; White and McKenzie, 1988; Molnar and England, 1990; Densmore and Hovius, 2000; Copley and McKenzie, 2007; Hoggard et al., 2016). Understanding how topography grows and decays is a fundamental geologic concern but also important for understanding chemical fluxes, the distribution of natural resources and biodiversity. For example, the elevation, history and erosion of topography are crucial components for understanding chemical fluxes to the oceans, weathering, atmospheric and oceanic circulation and biotic distributions (e.g., Raymo and Ruddiman, 1992; Anderson and Anderson, 2010; Herman et al., 2013; Perrigo et al., 2019). As such, topographic evolution plays a central role in understanding climate change throughout geological time (Mitrovica et al., 2020). Despite more than 100 years of study, defining and understanding histories of topographic growth and decay on geologic timescales remain important topics of research (e.g., Davis, 1899; Suess, 1906; Hack, 1975; Ziegler et al., 1985; Sahagian, 1987; Mitrovica et al., 1989; McDonough and Cross, 1991; Rowley, 2013). In this study we adapt existing paleobiological databases to produce 24,372 individual measurements of net uplift since Cretaceous times. These measurements are used to consider how lithospheric and sub-plate processes generate observed timings, amplitudes, and wavelengths of uplift. 


\section{Previous work}

In general, subsidence is better preserved in the geological record than uplift because erosion tends to remove the rock record we wish to measure. Uplift and associated landscape evolution is often estimated indirectly using proxies. A consequence of uplift is increased potential energy, which results in the erosion, transport and deposition of clastic material. As such, histories of solid sedimentary efflux at continental margins have been qualitatively and quantitatively related to patterns of uplift in most continents (e.g., Walford and White, 2005; Guillocheau et al., 2012; Galloway et al., 2011; Lodhia et al., 2018; Fernandes et al., 2019). Thermal and compaction histories of rocks can be linked to uplift via inferred histories of denudation (e.g., thermochronometry, vitrinite reflectance, sonic velocities; see Walford and White, 2005; Anderson and Anderson, 2010). Radiometric and biostratigraphic techniques can be used to date eroded surfaces, which in many places can be related to changes in base-level generated by, say, uplift (e.g., Bierman and Steig, 1996; Aciego et al., 2007; Finnegan et al., 2014; Stucky de Quay et al., 2019). Isotopic data, basalt morphology and paleobotany are also used to constrain elevation of topography via functions (lapse rates) that correlate, for example, temperature, or isotopic compositions, with elevation (e.g., Gregory and Chase, 1992; Garzione et al., 2000; Ghosh et al., 2006; Sahagian and Proussevitch, 2007; Chamberlain et al., 2012). Some of these observations have recently been shown to be self-consistent with predictions of uplift, denudation and sedimentary flux generated by inverting continental-scale drainage networks (see e.g., Fernandes et al., 2019).

A suite of geodetic and geologic observations exists to directly measure uplift and subsidence at a range of scales. For example, contemporary measurements of vertical motion from geodetic data (e.g., InSAR, GPS) have improved understanding of active tectonics and associated seismic hazards (e.g., Reilinger et al., 2010; Elliott et al., 2016). Uplifted, radiometrically dated Holocene terraces and historical records at tide gauges are crucial constraints on the viscoelastic response of the lithosphere and mantle to unloading (e.g., Lambeck et al., 1998; Watts, 2001; Pedoja et al., 2014). The least equivocal constraints on the history of uplift on timescales of tens of thousands to millions of years come from dated marine rock. Pioneering work, by for example Ziegler et al. (1985) and Sahagian (1987), showed that Cretaceous marine sedimentary strata across North America and Africa provide evidence for kilometer-scale, long wavelength, uplift during the last 100 million years (see also Holmes, 1965; Burke and Gunnell, 2008). Using these observations to determine uplift histories relies on accurate identification of marine lithologies and paleoenvironments. A general challenge with using these important inventories to constrain histories of, say, sub-plate support is their sparsity. In contrast, stratigraphy along passive margins and the relationship between age and depth of the oceans provide well resolved estimates of modern and ancient sub-plate support (see e.g., Czarnota et al., 2013; Hoggard et al., 2016; Lodhia et al., 2018; Morris et al., 2020).

Recent studies measuring vertical motions of continental topography on geologic timescales have similarly focused on mapping the difference between modern and paleo-elevations of dated sea-level markers (e.g., Bétard, 2010; Dorsey et al., 2011; Peulvast and Bétard, 2015; Bessin et al., 2017). These studies understandably tend to focus on regional scales (e.g. tens to hundreds of kilometers). Recently, the paleobiology community has assembled large inventories of paleontological data from across the globe to address large-scale paleobiological questions (e.g., paleodb.org; geobiodiversity.com). For example, genera in the Paleobiology Database (PBDB) include 24,372 records of Cretaceous to Recent marine fossil assemblages from all continents and many ocean islands. In this study we make use of that inventory and coincident elevation measurements to constrain uplift at $>24,000$ localities, which includes estimates for all continents and many ocean islands (Figure 1).

This paper has three parts. First, the simple methodology for measuring net uplift is explained using an example from western North America. The scheme used to assess the veracity of records in the PBDB, in particular the approach to identify extraneous records is explained. Uncertainties generated by paleobathymetry, postdeposition compaction and denudation, and sea level change are estimated. Second, amplitude, wavelength and timing of vertical motions for two case studies - the Western Interior of North America and Borborema Province, northeastern Brazil - are given. Finally, an example is provided of how net uplift measured using 
the PBDB can be used to give insight into the geologic evolution of continents. The uplift measurements are combined with geophysical observations (e.g., free-air gravity, shear and Pn-wave tomography) and simple isostatic calculations to elucidate the mechanisms responsible for generating the present-day elevation of continental topography.

\section{CALCULATION OF VERTICAL MOTIONS}

In many cases the current elevation of fossil assemblages on continents provides a reasonably good (minimum) constraint on net uplift since deposition. This result is a consequence of paleo-water depths in epicontinental seaways typically being small (less than a few hundred meters), post-deposition compaction tending to reduce elevations of uplifted marine rock, and far-field glacio-eustatic sea-level changes being of small amplitude $(<200 \mathrm{~m})$ compared to many (kilometer-scale) uplift estimates. However, in some places (e.g., where there is significant structural relief) these uncertainties can be important. Therefore the following sections describe procedures to calculate uplift and uncertainties from PBDB records. In its simplest form net uplift, $U$, is calculated as

$$
U=E+B-S+\Delta C
$$

where $E$ is present-day elevation of the marine fossil assemblage, $B$ is paleobathymetry, $S$ is sea-level at the time of deposition and $\Delta C$ is a correction that accounts for post-depositional compaction of sediments. Maximum and minimum estimates of uplift can be simply calculated using extreme uncertainties in elevation, paleobathymetry, sea level and compaction (e.g., $U_{\max }=E_{\max }+B_{\max }-S_{\min }+\Delta C ; U_{\min }=E_{\min }+B_{\min }-$ $\left.S_{\max }\right)$. If these quantities are measured with uncorrelated and random uncertainties (i.e. $\delta E, \delta B, \delta S, \delta \Delta C$ ) then uplift uncertainties, $\delta U$, can be calculated by quadrature, i.e. $\delta U=\left[(\delta E)^{2}+(\delta B)^{2}+(\delta S)^{2}+(\delta \Delta C)^{2}\right]^{1 / 2}$. Similarly, uncertainties in average uplift rate, $U^{\prime}=U / A$ where $A$ is sample age (with associated uncertainty $\delta A)$, can be expressed as $\delta U^{\prime}=\left|U^{\prime}\right|\left[(\delta E / E)^{2}+(\delta B / B)^{2}+(\delta S / S)^{2}+(\delta \Delta C / \Delta C)^{2}+(\delta A / A)^{2}\right]^{1 / 2}$. We note that we calculate surface uplift and that associated rock uplift can be significantly higher in denuded regions (e.g., England and Molnar, 1990).

The following sections describe the methodology used to calculate uplift with the aid of an example from the Prairie Canyon Member of the Mancos Shale, western Colorado (Figure 2; Kass, 1999). The key fossil assemblages at this locality are preserved within the siltstone part of this member and include shark teeth, Bacculites ammonites, inoceramid bivalves and mosasaur skull fragments. This stratigraphy was interpreted as Campanian in age based on the fossil assemblage and regional chronostratigraphic correlations (Obradovich and Cobban, 1975; Merewether and McKinney, 2015).

\section{Paleobiology Database (PBDB)}

Fossil occurrences were retrieved from the PBDB on $8^{\text {th }}$ July 2019 using the following filters: Maximum Age $=$ 100.5 Ma, Minimum Age = $0 \mathrm{Ma}$ (Cenomanian to Recent). The total number of records (fossils) downloaded was 580,637. This inventory contains information about age, location, stratigraphic origin (i.e. formation, unit, member), lithology, paleoenvironment and tectonic setting at the time of deposition and references to original source material. The inventory also identifies fossil assemblages, i.e., fossils that are located at the same site and stratigraphic level, which are usually obtained from cited studies.

The records obtained from the PBDB required modification prior to generating uplift constraints. The three most important modifications were as follows. First, all fossils identified as non-marine (i.e. 'terrestrial'), or those with no information about paleoenvironment, were removed from the database. Assemblages containing genera that do not necessarily represent marine conditions were also removed (e.g., birds that fly inland). For example, four records from inland Australia that document assemblages containing only species of the Pelecanidae family (pelicans) were removed. The total number of remaining marine fossil assemblages is 24,372. Each assemblage will subsequently be referred to as a point, and used to calculated uplift. Second, 
in general most points are accurately located. However, a small number are assigned incorrect locations in the database and must be corrected manually (e.g., whales off the coast of Hawaii were incorrectly assigned locations in Australia and Brazil). Locations of all key assemblages shown in this paper were checked and $<1 \%$ required manual intervention. Finally, qualitative paleoenvironmental information is converted into quantitative estimates of paleobathymetry. Paleoenvironmental information is recorded in the PBDB as, for example, 'shallow subtidal', 'estuary/bay', 'slope/basin', as is information about the tectonic setting, for example, 'passive margin', 'foreland basin'. The PBDB identifies 37 different paleoenvironments and 14 tectonic settings, accompanied by descriptions (See Figure 3; Table 1 for names and descriptions). The approach used to generate quantitative estimates of paleobathymetry is described in detail in the following section. Finally, points with poorly constrained paleobathymetry were corrected, where possible, using the methodology outlined below.

\section{Bathymetric model}

A variety of schemes exist to convert paleoenvironment descriptors into quantitative estimates of paleo-water depth (see Supplementary Material; e.g., Sahagian et al., 1996; Immenhauser, 2009). We used Immenhauser's (2009) scheme as it tends to yield conservative estimates of paleo-water depth, especially for shallow water environments (see Figure 3, Table 1). For example, we define water depths for 'very shallow marine' as $0-50 \mathrm{~m}$, 'shallow marine' as $0-100 \mathrm{~m}$, 'shelf' as $0-250 \mathrm{~m}$, 'upper bathyal' as $250-500 \mathrm{~m}$, 'middle bathyal' as $500-2000 \mathrm{~m}$, and 'lower bathyal' as $2000-4000 \mathrm{~m}$. We compared paleobathymetries calculated using this approach to 13 other schemes (see Table 2 in Supplementary Material). We find that there is generally close agreement between approaches. The most significant discrepancies are for shallow water environments $(<200$ $\mathrm{m}$ ), for which the Immenhauser conversion scheme tends to be more conservative (i.e. has the greatest range of water depths).

An important concern is whether the paleoenvironment of a given fossil assemblage reported in the PBDB is consistent with other paleoenvironmental interpretations for the same unit. To address this question we have benchmarked 14 randomly chosen points from North America, Africa and Europe against independent references (see Supplementary Material Table 3). For example, PBDB entry number 23,864 is an Eocene assemblage from the Bashi Member of the Hatchetigbee Bluff Formation of Alabama, US. It is reported in the PBDB as a sandstone deposited within a peri-reef or sub-reef environment by Palmer and Brann (1965). These deposits probably formed within a shelf environment in the vicinity of a reef but do not contain direct evidence of in-situ reef growth. Using our preferred conversion scheme they yield a paleo-water depth of 1-250 m (Table 1). An independent paleoenvironmental classification of the Bashi-Hatchetigbee Bluff deposits, which crops out as an East-West band in northern Alabama and Georgia, is given by Gibson and Bybell (1981). Based on foraminifera assemblages and sedimentology (e.g., the occurrence of shelly glauconitic silt and very fine grained sand, commonly including a thin sequence of laminated silt and clay at the top), they identify the depositional facies as inner shelf (inner to middle neritic, i.e. $<150 \mathrm{~m}$; Olson and Leckie, 2003). The other benchmarks are similarly consistent.

Table 1: Bathymetric model, descriptions of environments as given in the PBDB documentation, and attributed paleo-bathymetric ranges.

\begin{tabular}{|cllcc|}
\hline No. & Environment & Description & $\begin{array}{c}\min B \\
{[\mathrm{~m}]}\end{array}$ & $\begin{array}{c}\max \text { B } \\
{[\mathrm{m}]}\end{array}$ \\
\hline 1 & Basin Reef & Deep water reef growing close to basin floor. & 500 & 1000 \\
\hline 2 & Basinal (carbonate) & $\begin{array}{l}\text { On slope, basinal oozes that are predominantly } \\
\text { carbonate, deep-sea. }\end{array}$ & 500 & 3000 \\
\hline 3 & $\begin{array}{l}\text { Basinal } \\
\text { (siliciclastic) }\end{array}$ & On slope, terriginous mud, deep-sea. & 500 & 4000 \\
\hline 4 & Basinal (siliceous) & On slope, cherty deposits, deep-sea. & 500 & 4000 \\
\hline 5 & Carbonate indet. & $\begin{array}{l}\text { All carbonate deposits where environment of deposition } \\
\text { cannot be determined. }\end{array}$ & 0 & 3000 \\
\hline
\end{tabular}




\begin{tabular}{|c|c|c|c|c|}
\hline 6 & Coastal indet. & $\begin{array}{l}\text { Coastal environment where a specific non-deltaic setting } \\
\text { cannot be identified. }\end{array}$ & 0 & 50 \\
\hline 7 & Deep Subtidal & $\begin{array}{l}\text { Deposited between normal wave base and typical storm } \\
\text { wave base. }\end{array}$ & 15 & 50 \\
\hline 8 & $\begin{array}{l}\text { Deep Subtidal } \\
\text { Ramp }\end{array}$ & Ramp between normal and storm weather wave base. & 15 & 50 \\
\hline 9 & Deep Subtidal Shelf & $\begin{array}{l}\text { On flat shelf or platform between normal and storm } \\
\text { weather wave base. }\end{array}$ & 15 & 50 \\
\hline 10 & Deep-water indet. & Unspecified deep sea. & 250 & 4000 \\
\hline 11 & Delta Front & $\begin{array}{l}\text { Marine delta portion, more open marine, with significant } \\
\text { fresh water input. }\end{array}$ & 1 & 15 \\
\hline 12 & Estuary/Bay & $\begin{array}{l}\text { Shallow water with fresh water influence; perpendicular } \\
\text { to shore, including wave base. }\end{array}$ & 0 & 15 \\
\hline 13 & Foreshore & $\begin{array}{l}\text { Coastal. Sandstone with gently dipping planar cross } \\
\text { lamination with minimal bioturbation. }\end{array}$ & 0 & 1 \\
\hline 14 & $\begin{array}{l}\text { Interdistributary } \\
\text { Bay }\end{array}$ & $\begin{array}{l}\text { Delta with marine influence, at sea level and may contain } \\
\text { marine to brackish water faunas. }\end{array}$ & 0 & 2 \\
\hline 15 & Intraplatform Reef & $\begin{array}{l}\text { Reef in shallow-water portion of a platform, but not near } \\
\text { its margin. }\end{array}$ & 0 & 100 \\
\hline 16 & $\begin{array}{l}\text { Lagoonal/Restricted } \\
\text { Shallow Subtidal }\end{array}$ & $\begin{array}{l}\text { Up to a few meters of water depth, hyposaline, restricted } \\
\text { water movement. }\end{array}$ & 0 & 2 \\
\hline 17 & Lagoonal & $\begin{array}{l}\text { Up to a few meters of water depth, hypersaline. Shallow } \\
\text { marine with fresh water; influence parallel to shore, } \\
\text { including wave base. Carbonate or siliciclastic. }\end{array}$ & 0 & 5 \\
\hline 18 & $\begin{array}{l}\text { Marginal Marine } \\
\text { indet. }\end{array}$ & $\begin{array}{l}\text { Shallow setting, dominated by wave, river and tidal } \\
\text { processes. Depositional settings include delta, beach, } \\
\text { barrier island, estuarine, lagoonal, tidal flat. }\end{array}$ & 0 & 15 \\
\hline 19 & Marine indet. & All marine siliciclastic deposits. & 0 & 4000 \\
\hline 20 & Offshore & $\begin{array}{l}\text { Below typical storm wave base, although can be affected } \\
\text { by exceptionally strong storms. On the continental slope. } \\
\text { Shale with storm sand beds, pervasive bioturbation of } \\
\text { Cruziana. }\end{array}$ & 50 & 250 \\
\hline 21 & Offshore indet. & $\begin{array}{l}\text { Below typical storm wave base, although can be affected } \\
\text { by exceptionally strong storms. On the continental slope. } \\
\text { Unknown platform geometry. }\end{array}$ & 50 & 250 \\
\hline 22 & Offshore Ramp & $\begin{array}{l}\text { Carbonate platforms which have a very low gradient } \\
\text { depositional slope (commonly less than } 0.1 \text { ) from a } \\
\text { shallow-water shoreline or lagoon to a basin floor. }\end{array}$ & 50 & 250 \\
\hline 23 & Offshore Shelf & $\begin{array}{l}\text { The term shelf is more widely used in geologic context for } \\
\text { any broad, gently-sloping surface, clastic or carbonate, } \\
\text { which has a break in slope in deeper water. }\end{array}$ & 50 & 250 \\
\hline 24 & $\begin{array}{l}\text { Open Shallow } \\
\text { Subtidal }\end{array}$ & $\begin{array}{l}\text { Up to a few meters of water depth, normal marine } \\
\text { salinities. }\end{array}$ & 1 & 15 \\
\hline 25 & Paralic indet. & $\begin{array}{l}\text { Shallow marine, cannot distinguish between lagoon or } \\
\text { estuary, including wave base. }\end{array}$ & 0 & 15 \\
\hline 26 & Peri-reef or Sub-reef & $\begin{array}{l}\text { Carbonate deposits in the vicinity of a reef, however not } \\
\text { containing in-situ reef growth. }\end{array}$ & 1 & 250 \\
\hline 27 & Peritidal & $\begin{array}{l}\text { Shallow marine. Includes supratidal and intertidal } \\
\text { settings and may be characterized in arid climates by } \\
\text { evaporite minerals, dolomite, and desiccation cracks, but } \\
\text { in humid climates by bioturbated mudstones with } \\
\text { fenestral pores. }\end{array}$ & 0 & 2 \\
\hline
\end{tabular}




\begin{tabular}{|c|c|c|c|c|}
\hline 28 & $\begin{array}{l}\text { Platform/Shelf- } \\
\text { margin } \\
\text { Reef }\end{array}$ & Located on a carbonate platform margin. & 0 & 250 \\
\hline 29 & Prodelta & $\begin{array}{l}\text { Deeper marine delta portion, mud-dominated, difficult to } \\
\text { distinguish from offshore deposits. }\end{array}$ & 15 & 100 \\
\hline 30 & $\begin{array}{l}\text { Reef, Buildup or } \\
\text { Bioherm }\end{array}$ & $\begin{array}{l}\text { Reef of uncertain geographical position relative to the } \\
\text { shore or continental shelf margin. }\end{array}$ & 0 & 250 \\
\hline 31 & Sand Shoal & $\begin{array}{l}\text { Strong wave or tidal currents and consequently displays } \\
\text { large-scale trough cross-stratification of well-sorted } \\
\text { grainstone, but may also display seaward-inclined } \\
\text { laminae where it is developed in a foreshore setting. }\end{array}$ & 0 & 15 \\
\hline 32 & $\begin{array}{l}\text { Shallow Subtidal } \\
\text { indet. }\end{array}$ & Up to a few meters of water depth, salinity undetermined. & 1 & 15 \\
\hline 33 & Shoreface & $\begin{array}{l}\text { Coastal. Sandstone with large-scale trough cross-bedding } \\
\text { and Skolithos. On weak wave climate, may be highly } \\
\text { bioturbated with wave-ripple laminae. }\end{array}$ & 1 & 50 \\
\hline 34 & Slope & Slumps, slides, debrites, turbidites. & 250 & 4000 \\
\hline 35 & Slope/Ramp Reef & Growing on a shelf slope or carbonate ramp. & 50 & 250 \\
\hline 36 & Submarine Fans & $\begin{array}{l}\text { Deep water depositional systems generated by turbidity } \\
\text { currents, often associated with a delta system. }\end{array}$ & 1500 & 4000 \\
\hline 37 & $\begin{array}{l}\text { Transition Zone/ } \\
\text { Lower Shoreface }\end{array}$ & $\begin{array}{l}\text { Coastal. Mudstone and hummocky cross-stratified } \\
\text { sandstone, mixed Skolithos-Cruziana. }\end{array}$ & 15 & 70 \\
\hline
\end{tabular}

At face value the largest paleo-water depth uncertainties are associated with 11,447 assemblages recorded as forming in indeterminate marine environments (i.e. 'marine indet.'). However, many records contain comments that provide additional information that can be used to improve estimates of paleo-water depth. These 'geologic comments' are often excerpts from publications from which the database entries were made. This additional information was also used to ensure consistency between the database and original publications. For example, the point numbered 10,119 is a fossil assemblage from the Gram Formation, Denmark (Tortonian; $11.6-7.2 \mathrm{Ma})$. It was recorded in the database as 'marine indet.' and no indication of tectonic setting was given. However, the 'geologic comments' noted that "[the] Gram Formation was deposited in a marine environment at a depth between 50 and $100 \mathrm{~m}$, as indicated by the marine flora associated with terrestrial material, foraminifera and the marine fauna". These more precise estimates were used to modify the database entry. All entries corrected in this way are labeled ' $b$ ' in the inventory of uplift constraints (see Supplementary Material). If the 'geologic comments' did not provide additional information on the source of the data (e.g., the original paper) then other publications were consulted. These points are labeled 'c' in the data tables provided and associated citations are given in Supplementary Material. Any points that were not corrected using either of these two methodologies are labeled 'a'. Of the 12,765 points that have accurate paleo-water depth records $>90 \%$ have minimum paleo-water depth estimates of $50 \mathrm{~m}$ or less, and maximum paleo-water depth estimates of $250 \mathrm{~m}$ or less (see Supplementary Material).

As another example, consider the fossil assemblage shown in Figure 2. The PBDB entry is consistent with the original publication, which places the assemblage near Cedaredge, Colorado, on the easternmost portion of the Book Cliffs and states that it is contained within the "Mancos B" (the Prairie Canyon) Member of the Mancos Shale (Cole et al., 1997). The depositional environment is interpreted as offshore marine based on sedimentary architecture and fossil assemblage (mosasaur, shark teeth, ammonites and bivalves). This interpretation is consistent with that of Hampson (2010) who examined the sedimentology of distal portions of the Prairie Canyon Member in western Colorado. Using our preferred conversion scheme (Table 1) the paleo-water depth range for this assemblage is $150 \pm 100 \mathrm{~m}$ (see Figure 2). In the following sections we examine two other potentially significant sources of error: sea-level and compaction. 


\section{Sea-level}

Global changes in sea-level are challenging to constrain accurately on geological timescales. Many previous attempts have made use of two techniques. The first is identifying anomalous subsidence patterns from backstripped stratigraphy in regions with supposedly well understood tectonic histories (e.g., rifting and cooling of passive margins; Watts and Steckler, 1979). The second correlates stratigraphy from supposedly stable, or well understood, continental margins or interiors (e.g., Vail et al., 1977). Bessin et al. (2017) presented a compilation of global sea-level curves produced using a suite of different methodologies (coastal onlap analysis, continental flooding, backstripping, ocean floor age-depth-area and isotope proxies; Haq et al., 1987; Haq and Al-Qahtani, 2005; Scotese and Golonka, 1992; Smith et al., 1994; Miller, 2005; Kominz et al., 2008; Müller et al., 2008; Miller et al., 2011; Rowley, 2013). The compilation shows significant discrepancies between estimates of eustasy $(100-200 \mathrm{~m}$ for some stages). These discrepancies are not surprising given that many estimates of glacio-eustasy are based on regional datasets in places where the stability (or predictability) of continental vertical motions is assumed. The role of mantle convection and complex hydrodynamic processes in modifying the vertical motions of supposedly stable continents and sea level is generally poorly understood on geological timescales but important (e.g., ocean syphoning: migration of water caused by surface deflections; Mitrovica and Milne, 2002; Moucha et al., 2008a; Flament et al., 2013; Austermann et al., 2017). Amplitudes of global sea-level change are estimated to vary by as much as as $200 \mathrm{~m}$, whilst mantle-driven processes can produce changes in vertical motions of similar or greater amplitudes, and comparable timescales (Miller, 2005; Lovell, 2010). For example, backstripping of stratigraphy along passive margins combined with upper mantle shear wave tomographic models indicate that sub-plate support can generate up to $\sim 1 \mathrm{~km}$ of uplift or subsidence at $\sim 10-10,000 \mathrm{~km}$ wavelengths, on timescales of $1-100 \mathrm{Ma}$ (e.g., Czarnota et al., 2013; Flament et al., 2013; Lodhia et al., 2018; Morris et al., 2020).

A pragmatic way to assess the impact of sea-level on calculated uplift is to use the range of values given for each stage in the compilation of Bessin et al. (2017). The extrema for each stage are used to define sea-level uncertainties, $\delta S$, and uplift is corrected by the mean value. Present-day sea-level is used as the reference frame for all measurements and paleo-sea level uncertainties are between $-99 \mathrm{~m}$ and +264 m (see Supplementary Material).

\section{Compaction correction}

Post-deposition compaction of strata means that measurements of net uplift from elevations of fossil assemblages are minima (Figure 2). Correcting for compaction is not necessary for sedimentary rock that satisfies two criteria. First, they were deposited directly upon rock that will not compact significantly (e.g., crystalline basement; previously compacted rock). Second, they were not subsequently buried. However, many of the fossil assemblages within the database are contained within stratigraphy from sedimentary basins that accumulated significant stratal thicknesses before and after their deposition. Therefore a strategy for correcting for compaction is required.

The compaction correction, $\Delta C$, is calculated by decompacting the thickness of underlying sedimentary rock, $C_{c}$, by removing overlying rock of thickness $D$. Porosity is parameterized using the well-known formulation by Athy (1930)

$$
\phi(z)=\phi_{\circ} \exp \left(-\frac{z}{\lambda}\right)
$$

where $\phi_{\circ}$ and $\lambda$ are initial porosity and compaction wavelength, respectively, $z$ is depth. Assuming that the solid fraction remains constant during compaction, the decompacted thickness is given by

$$
\int_{D}^{D+C_{c}}[1-\phi(z)] \mathrm{d} z=\int_{0}^{C_{d}}[1-\phi(z)] \mathrm{d} z
$$

where $D$ is the amount of denudation, $C_{c}$ and $C_{d}$ are compacted and decompacted sedimentary layer thicknesses, respectively. Substitution with Equation 2 and solving the integral gives

$$
C_{d}=C_{c}+\phi_{\circ} \lambda\left[\exp \left(-\frac{D+C_{c}}{\lambda}\right)-\exp \left(-\frac{D}{\lambda}\right)+1-\exp \left(-\frac{C_{d}}{\lambda}\right)\right] .
$$


$C_{d}$ is solved iteratively for each layer using the Newton-Raphson method. The resulting compaction correction is $\Delta C=C_{d}-C_{c}$.

Compaction parameter values can be obtained from well data, for example, from direct measurements of porosity or via indirect means (e.g., the relationship between velocity and porosity; Wyllie et al., 1956). Values of $\phi_{\circ}$ and $\lambda$ can range from $0.25-0.7$ and $1.4-3.7 \mathrm{~km}$, respectively, in siliciclastic sediments, and $0.4-0.8$ and $1.2-6.0 \mathrm{~km}$ in carbonates (Magara, 1980; Sclater and Christie, 1980; Goldhammer, 1997). Notwithstanding these constraints, estimates of $C_{c}$ and $D$ are usually minima because we cannot constrain how much of the sedimentary pile has been lost by erosion. For simplicity we have not applied this correction to the full database and explore compaction corrections on a case-by-case basis.

Figure 4 shows an example of applying a compaction correction to the test case in western North America. This fossil assemblage was deposited within the Piceance basin, which contains thick Cambrian to Pliocene sedimentary rock (Johnson, 1992). The stratigraphy consists of predominantly siliciclastic deposits (sandstones and shales; UUPA Team, 2003). The exact value of $C_{c}$ depends on whether all Mesozoic sedimentary rock or only Cretaceous deposits ought to be decompacted $\left(C_{c_{1}}=1.4 \mathrm{~km}\right.$ and $C_{c_{2}}=2.7 \mathrm{~km}$, respectively; Figure 4; Hintze and Kowallis, 2009). Existence of a regional Lower Cretaceous unconformity throughout the Western Interior Basin suggests Early and Mid-Mesozoic rocks of the western Cordillera were compacted and partly eroded during Sevier orogenesis (e.g., Bjerrum and Dorsey, 1995; Heller and Paola, 1989). We therefore initially assume that they were not compacted by deposition of Cretaceous to Recent stratigraphy. Instead, we start by assuming that only Cretaceous sedimentary rock was affected by compaction, i.e. $C_{c}=1.4 \mathrm{~km}$. Thickness of denuded rock, $D$, can be tentatively estimated from preserved thicknesses of sedimentary rock in adjacent non-eroded sections or neighboring basins of similar stratigraphy. This correction ought to be applied on a case-by-case basis because lateral changes in facies or structural variations can affect thickness estimates. $D$ ranges from $0.8-2.9 \mathrm{~km}$ for this example (e.g., Hintze and Kowallis, 2009). Published porosity-depth data from wells in the adjacent Uinta Basin, which contain similar stratigraphy, have best-fit values of $\phi_{\circ}=0.25$ and $\lambda=3.0 \mathrm{~km}$ (Chapman et al., 1984). These compaction parameters, combined with the range of values of $C_{c}$ and $D$, result in a compaction correction (additional uplift) of $0.08-0.31 \mathrm{~km}$ for the example shown in Figure 4 .

\section{Elevation}

Locations in the PBDB are typically reported with an accuracy of at least $0.01^{\circ}(\sim 1 \mathrm{~km}$ at the equator). However, present-day elevation of each fossil assemblage is not usually provided. Instead it was extracted from digital elevation data. Elevations were extracted from the ETOPO1 digital elevation model, which has a grid spacing of one arc minute $(\sim 1.85 \mathrm{~km})$ and sea-level as the vertical datum (Amante and Eakins, 2009). Other datums, such as mean high water, and mean low water, typically differ by less than the vertical accuracy of ETOPO1, which is of order 10 meters. We note that ETOPO1 was generated using weighted means from the SRTM30 data set (horizontal resolution $\sim 30 \mathrm{~m}$ ) and the GLOBAL digital elevation model, which was used to fill in gaps (Amante and Eakins, 2009). Higher resolution digital elevation data (e.g., ASTER, TanDEM-X) could also be used to extract information about elevation. For the PBDB points located in western North America and the Borborema Province, elevations from ETOPO1 differ from SRTM30 by $<60 \mathrm{~m}$, which is significantly less than nearly all paleo-water depth uncertainties. The present-day elevation of our example from western North America is $1.90 \mathrm{~km}$ (Figure 2).

\section{GLOBAL PATTERNS OF UPLIFT}

Figure 5 shows the inventory of global uplift measurements calculated by combining present-day elevation, paleo-water depth and sea-level (Equation 1). Compaction corrections were not included for simplicity, as such, Figure 5 shows minimum net uplift. The collection of uplift measurements is particularly dense along the coastlines of most continents, as well as in western North America, Europe, Japan and New Zealand. Figure 5b-e shows examples of cross sections in places where the density of the inventory is such that uplift at 
large length scales $(\sim 100-1000 \mathrm{~km})$ can be constrained. For example, a reasonably densely sampled transect can be constructed from northernmost North America to the southern tip of South America (Figure 5b). This transect includes the Yukon Plateau, Rocky Mountains, Mexican Highlands, the Andes, Altiplano, and Patagonia. A prominent feature of this transect is the $>2000 \mathrm{~km}$ wide post-Cretaceous domal swell centered on the Colorado Plateau in western North America. Patterns of uplift in the Andes and Altiplano contain shorter wavelength $(<500 \mathrm{~km})$ relatively large, kilometer-scale, changes in net uplift. Transects through the southern Appalachian Mountains, North America, indicate that the topography there has been uplifted and tilted by $\sim 300 \mathrm{~m}$ during the last $\sim 40 \mathrm{Ma}$. These results are a consequence of careful biostratigraphic mapping by Kirkland (1996), Keller et al. (2002), Sulser et al. (2010) and many others. Citations to primary literature for all points are included in the data tables provided as Supplementary Material.

The inventory contains important, albeit sparse, measurements of uplift from within continental interiors. In northwest Africa the distribution of nearshore continental, marginal marine, and open marine fossils record the existence of a Cretaceous-Paleogene trans-Saharan seaway extending from the Gulf of Guinea, across Mali and Nigeria, to the present-day Mediterranean (e.g., Berggren, 1974; Tintant et al., 2001; Tapanila et al., 2008; Boyden, 2011; O'Leary et al., 2019). Figures 5c-d show $\sim 300 \mathrm{~m}$ of net uplift across western Africa, and $\sim 600 \mathrm{~m}$ of post-Paleocene differential uplift of the Tibesti dome. Figure 5e shows $2 \mathrm{~km}$ of post-Oligocene uplift of the Caucasus Mountains and uplift measurements atop the Urals and the west Siberian Plain.

In eastern Australia, fossils from the shallow-marine Mackunda Formation, deposited during the final marine regression within the Eromanga basin, show a tilt of $\sim 200 \mathrm{~m}$ with a wavelength of $\sim 200 \mathrm{~km}$. These observations complement those generated from correlation and backstripping of well data (Gallagher and Lambeck, 1989). Figure 5 contains many other examples of useful spot measurements of uplift, especially across South America and Eurasia. We examine two case studies in more detail: Western North America and the Borborema Province, Brazil.

\section{Western North America}

Cretaceous flooding of western North America resulted in widespread deposition and preservation of marine rock within the continental interior (Figure 6; e.g., Sloss, 1963; Cross and Piliger, 1978). Extensive exploration in the region has generated a well-constrained and generally accepted chronostratigraphy, as well as a large number of sedimentological and paleoenvironmental studies (Obradovich and Cobban, 1975; Roberts and Kirschbaum, 1995; Johnson et al., 2002; Gani et al., 2015; Merewether and McKinney, 2015).

Paleobathymetric estimates from the PBDB broadly agree with independent values. For example, they are consistent with local water-depth maxima estimated using the height of clinoforms (40 m, Plint et al., 2009), planktonic to benthic foraminifera ratios (500 m, Eicher , 1969) and numerical simulation of oceanic circulation (100-400 m, Ericksen and Slingerland, 1990; Dean et al., 2019). Arthur and Sageman (2004) correlated depositional environments, lithofacies and water depths in modern marine settings to infer maximum water depths of 200-300 m across most of the Cretaceous seaway, with local maxima of $1000 \mathrm{~m}$. These values and smoothly varying paleowater-depth estimates indicate that a modern analogue is the Hudson Bay, a large, $\sim 1000 \mathrm{~km}$-wide seaway that has an undulated bottom in most parts and a mean water depth of $\sim 150 \mathrm{~m}$ (GEBCO; Stewart and Lockhart, 2006).

The distribution of Cretaceous marine rocks within western North America today defines a domal swell centered on the Colorado Plateau (Figure 6d). Maximum uplift along the mountain belt increases to the south, from $\sim 1.5 \mathrm{~km}$ in the Northern and Canadian Rockies (Figure 6e), to $2-2.5 \mathrm{~km}$ in the Middle Rockies (Figure 6f). The Southern Rocky Mountains and Colorado Plateau are foci of maximum post-Cretaceous net uplift $(2.5-3 \mathrm{~km}$; Figure 6g). Towards the east post-Cretaceous uplift decreases to $\sim 0.5 \mathrm{~km}$ in the Great Plains where easternmost Cretaceous marine rocks are recorded. Previous studies of tilting or epeirogenic vertical motions in this region have made use of reconstructed Cretaceous sedimentary isopachs (Cross and Piliger, 1978; Sahagian, 1987; Mitrovica et al., 1989). The new PBDB measurements provide additional direct constraints on uplift, including patterns of post-Cretaceous tilting across most of western North America. 
These isopach maps can be used to assess the importance of compaction of Cretaceous sediments in affecting calculated uplift (e.g., Cross and Piliger, 1978; Mitrovica et al., 1989; Roberts and Kirschbaum, 1995). Reconstructed Upper Albian to Santonian isopachs indicate that up to $4 \mathrm{~km}$ of sedimentary rock in foreland basins formed as a result of loading by the Sevier orogen. Foci of thick sedimentary rock are in north-central Utah, southern Wyoming and southeast Idaho. Elsewhere, for example in eastern Colorado, eastern Wyoming, central Montana and New Mexico, mapped thicknesses are less than $500 \mathrm{~m}$. Campanian to Maastrichtian isopachs record a different pattern of sedimentation. The thickest isopachs $(2-3 \mathrm{~km})$ are centered on eastern Wyoming and western Colorado. Thicknesses of less than $500 \mathrm{~m}$ are mapped eastwards of central North Dakota, South Dakota, Nebraska and Kansas. These observations suggest that the maximum sediment thickness that could have been compacted, $C_{c}$, is $\sim 6 \mathrm{~km}$ (in northeast Utah/southeast Wyoming), decreasing to zero towards the easternmost extent of the basin (e.g., eastern Minnesota).

Maximum denudation, $D$, can be approximated using the thickness of Cenozoic sedimentary rock preserved within the Laramide intermontane basins (e.g., Hintze and Kowallis, 2009). For example, the Uinta Basin, Utah, contains up to $5.9 \mathrm{~km}$ of post-Cretaceous sedimentary rock, which we regard as a conservative (maximum) estimate of the amount of material denuded from other parts of western North America. Apatite fission track analyses of Late Cretaceous sedimentary rock, from outcrops within the Rocky Mountains, provide further evidence of $\sim 4-6 \mathrm{~km}$ of denudation since the deposition of Cretaceous marine rock (e.g., Herman et al., 2013). By taking into account the range of possible $\phi_{\circ}$ and $\lambda$ values the compaction correction is a maximum of $0.24-2.5 \mathrm{~km}$ centered on the Southern Rocky Mountains. For easternmost points, which sit directly above basement, their compaction correction is zero (Dyman et al., 1994). Assuming an average $\phi_{\circ}=0.5$ and $\lambda=3.6 \mathrm{~km}$ the compaction correction would amplify the differential rock uplift between the Great Plains and Southern Rocky Mountains by $\sim 1.3 \mathrm{~km}$.

There are a suite of additional uplift and denudation constraints that can be brought to bear to understand the evolution of North American topography. For example, Fernandes et al. (2019) synthesized a suite of observations including stable isotopes, palynology, radiometrically dated incision, thermochronology and additional stratigraphic observations. They used a subset of uplift measurements generated from the PBDB and stratigraphic observations to test the results of a continent-wide inversion of drainage patterns. The inverse methodology uses families of drainage networks to recover smooth spatio-temporal uplift rate histories using a calibrated stream power erosional model (e.g., Roberts et al., 2012). That approach provides a means to fill in gaps between spot measurements of post-Cretaceous uplift.

\section{Borborema Province, northeast Brazil}

The second example is from northeastern Brazil, which includes the Borborema Province and Cretaceous rift basins. Figure 7 shows the spatial and temporal distribution of PBDB points, interpreted paleo-water depths and calculated uplift for the region. The broad domal swell of the region, with a diameter of $900-1000 \mathrm{~km}$ and amplitude of $700 \mathrm{~m}$, is illustrated in the cross-sections shown (Figure 7e-f). Calculated post-Aptian net uplift is $>700 \mathrm{~m}$.

The key constraint on large-scale uplift of this region is the presence of late Aptian-Cenomanian shallow marine deposits of the Romulado Formation at 700 - $900 \mathrm{~m}$ elevation within the Araripe basin (Figure 7a). A fossil assemblage from this deposit is recorded in the PBDB and geologic mapping shows that this unit crops out as a thin band close to the top of the Araripe Plateau (Figure 7a). The Romulado Formation, which is part of the Santana Group, forms a 3-5 m thick, shallowly dipping, black shale that is well known for excellent fossil preservation (e.g., Martill, 1988). Marine microfossils recovered in the well 2-AP-1-CE (dinoflagellate cysts, ostracodes and foraminifera), and a fossil-bearing layer towards the top of the formation containing Cretaceous gastropods, bivalves and echinoderms provides evidence of lagoonal and estuarine environments during a Cretaceous marine transgression (Arai and Coimbra, 1990; Coimbra et al., 2002; Prado et al., 2016; Pereira et al., 2016). Sedimentological evidence for marine depositional environments, including tide-dominated coastal facies and storm-dominated shelf sedimentation, further attests to the marine origin of the Romulado Formation 
(Custódio et al., 2017). Absence of marine sediments in the Lower Cretaceous rift basins located in between the Araripe and Potiguar basins (e.g., Rio do Peixe, Icó, Lima Campos, Iguatu and Lavras da Mangabeira basins) suggests that this portion of the continental interior might not have been inundated by marine waters in the Cretaceous Period (Arai, 2009). Paleoflow measurements of fluvial deposits below and above the Santana Formation in the Araripe and Tucano-Jatobá basins, the Marizal and Exu Formation, respectively, show a change from the southeast to west-southwest directions, indicating a redirection of regional drainage towards the Parnaíba Basin likely caused by regional uplift and tilting (Assine, 1994; Freitas et al., 2017). These data suggest incipient uplift soon after the deposition of the marine units.

Aptian to Cenomanian shallow marine fossil-bearing outcrops occur at lower elevations in the onshore portions of the Atlantic rift basins (Potiguar, Pernambuco-Paraíba, Sergipe-Alagoas). Within the Potiguar Basin, shallow marine sedimentation in lagoonal, estuarine and reefal environments is recorded by the deposition of the Jandaíra Formation (92-91 Ma), which crops out extensively throughout the onshore portion of the basin (Pessoa Neto et al., 2007; Garcia et al., 2014). Additional regional paleobathymetric constraints are provided by marine stratigraphy to the west. Strontium isotope ratios, organic biomarkers and fossil assemblages indicate that the Albian Codó Formation of the Parnaíba Basin was deposited under marine conditions (Rodrigues, 1995; Antonioli et al., 1999, Figure 7a).

Evidence of Cenozoic vertical motions along the modern coastal margins of this region comes from the Pirabas and Barreiras Formations (Rossetti et al., 2013, Figure 7a, yellow polygons). The Pirabas Formation is a fossilrich marine carbonate-siliciclastic deposit which crops out along Brazil's equatorial margin. Foraminifera and pollen biostratigraphy date it as late Oligocene-early Miocene in age. Sedimentological and paleontological evidence suggests the unit was deposited in a shallow inner shelf, lagoonal, shoreface, foreshore and marginal marine environment. The Barreiras Formation overlies the Pirabas Formation, and is predominantly a siliciclastic deposit that is exposed in a $\sim 100 \mathrm{~km}$-wide band along the northeastern coast of Brazil. Mostly afossiliferous, chronostratigraphic constraints based on pollen and (U-Th)/He-dated overlying laterites constrain the age as early-middle Miocene, with an upper age limit of $16.45 \mathrm{Ma}$ (Rossetti et al., 2013). Although previously interpreted as a continental fluvial-alluvial deposit, sedimentological evidence of widespread bidirectional flow, mud drapes, reactivation surfaces, rhythmites and ichnofossils suggests a tidally influenced estuarine paleoenvironment (e.g., Rossetti and Santos Jr., 2004). The variable present-day elevation of the Pirabas and Barreiras Formations, from $\sim 20 \mathrm{~m}$ above sea level in the equatorial and southern regions up to $\sim 150 \mathrm{~m}$ in easternmost regions, indicates post-depositional upwarping of this paleo-surface since the midMiocene (Rodríguez Tribaldos et al., 2017).

Within the Potiguar Basin, an angular unconformity of Aptian-Albian age $(\sim 110 \mathrm{Ma})$ suggests that only postrift sediments were significantly compacted by Cretaceous to Recent sedimentation (Pessoa Neto et al., 2007). The thickness of Cretaceous sediments $\left(C_{c}\right)$ onshore is at most $\sim 2.2 \mathrm{~km}$ and post-Cretaceous deposits $(D)$ are $\sim 1 \mathrm{~km}$ thick $\left(\right.$ Ojeda, 1983). If we assume that $\phi_{\circ}=0.5$ and $\lambda=3.6 \mathrm{~km}$ (i.e. mean values for carbonates and clastics) the compaction correction $(\Delta C)$ is $267 \mathrm{~m}$. This value is conservative as the largest thicknesses are confined to localized depressions. A similar exercise can be performed for other Atlantic rift basins. For example, the maximum value of $\Delta C$ in the Pernambuco-Paraíba Basin is $9 \mathrm{~m}$ (for $C_{c}=397 \mathrm{~m}, D=95 \mathrm{~m}$; Barbosa et al., 2007), and in the Sergipe-Alagoas Basin it is $234 \mathrm{~m}$ (for $C_{c}=1000 \mathrm{~m}, D=1500 \mathrm{~m}$; Campos Neto, 2007; Ojeda, 1983). For the onshore Araripe Basin, thickness of Cretaceous stratigraphy beneath the Santana Formation is $\sim 500 \mathrm{~m}$, and $30-350 \mathrm{~m}$ of post-Santana sedimentary rock caps the Araripe plateau (Assine, 1994, 2007). Assuming that no additional sediments were deposited above the plateau (Peulvast and Bétard, 2015), $\Delta C$ ranges from 4-38 m. These maximal compaction corrections are not included in Figure $7 \mathrm{~d}$ for simplicity.

Additional constraints on uplift and denudation in the region include the non-fossiliferous, terrestrial siliciclastic deposits of the Serra dos Martins Formation (Morais Neto et al., 2009; Oliveira and Medeiros, 2012), which are found capping many high mesas in the northern Borborema Plateau. Ages of detrital apatite and zircon within these fluvial sedimentary rocks suggest sedimentary deposition cannot be older than Paleogene (Morais Neto et al., 2009). These results indicate that the region was subaerial by Paleogene times. Cenozoic basalt 
flows crop out atop mesas within the central and northern parts of the province: ${ }^{40} \mathrm{Ar} /{ }^{39} \mathrm{Ar}$ dating of some flows indicates that they have a minimum age of $\sim 25 \mathrm{Ma}$ (Menezes et al., 2003; Jardim de Sá et al., 2005). These observations have been interpreted as a record of Paleogene to Recent uplift. Vitrinite reflectance data, thermal maturity analysis and overcompacted sedimentary rock from the Recôncavo-Tucano-Jatobá basins in the southeastern part of the province suggest at least $1750 \mathrm{~m}$ of rock has been eroded since Cretaceous times (Figure 7; Magnavita et al., 1994).

\section{DISCUSSION}

This study has generated a quantitative inventory of net uplift measurements from the continents and ocean islands. In the previous section, results from western North America, where the inventory is relatively dense, and the Borborema Province where recorded fossil assemblages are more sparse, were examined. In this section we explore how such uplift measurements can be used to generate useful geologic insight. Here the uplift measurements are combined with simple calibrated isostatic calculations to constrain origins of topography. To do so, we use seismological observations from the USArray experiment and a recent deployment of broadband seismometers in the Borborema province (e.g., Luz et al., 2015a,b; Buehler and Shearer, 2016). This simple approach assumes that flexural rigidity of the lithosphere is sufficiently low such that uplift at wavelengths $\gtrsim 100 \mathrm{~km}$ is broadly isostatic. This assumption is probably reasonable for western North America and Borborema where the relationship (admittance) between free-air gravity and topography in the frequency domain indicate elastic thicknesses, $T_{e}$, of $12 \pm 2 \mathrm{~km}$ and $3 \mathrm{~km}$, respectively (Stephenson et al., 2014; Rodríguez Tribaldos et al., 2017). Admittance calculated using spherical wavelets indicate similarly low $(\lesssim 20 \mathrm{~km})$ values of $T_{e}$ for these regions (Audet, 2014). We acknowledge that other approaches can be used and suggest that the inventory could be helpful in assessing predictions from, for example, geodynamic models of mantle convection (e.g., Flament et al., 2013).

Correlations between elevation and crustal thicknesses in western North America and the Borborema province are weak (Roberts et al., 2012; Rodríguez Tribaldos et al., 2017, Figure 8). Instead, the three primary candidates for generating support of topography (and uplift) are modification to the density and thickness of the lithosphere, or the convecting mantle. Following the approach of McNab et al. (2018) and Klöcking et al. (2018a), we explore the effects of lithospheric thinning, depletion and excess asthenospheric mantle temperature on the expected elevation of continents (Figure 9). Assuming isostasy prevails (i.e. flexural effects are minimal and viscous stresses related to deeper mantle flow can be neglected), the expected elevation, $e$, of a column of lithospheric material and associated asthenospheric mantle with respect to the depth of a standard mid-ocean ridge is given by

$$
e=t_{c c}\left(\frac{\rho_{L}-\rho_{c c}}{\rho_{a}}\right)-t_{w}\left(\frac{\rho_{a}-\rho_{w}}{\rho_{a}}\right)-t_{o c}\left(\frac{\rho_{a}-\rho_{o c}}{\rho_{a}}\right)+(a-x)\left(\frac{\rho_{a}-\rho_{L}}{\rho_{a}}\right)+b\left(\frac{\rho_{a}-\rho_{c a}}{\rho_{a}}\right)
$$

where $t_{w}$ and $\rho_{w}$ are the mean depth and density of water at a mid-ocean ridge, and $t_{o c}$ and $\rho_{o c}$ are the mean thickness and density of oceanic crust, respectively. $t_{c c}$ is variable thickness of continental crust (30$40 \mathrm{~km}), \rho_{c c}$ is density of continental crust. $a$ is lithospheric thickness, $b$ is thickness of asthenospheric mantle that contributes to uplift and $x$ is the thickness of lithospheric mantle removed. $\rho_{a}$ and $\rho_{c a}$ are densities of asthenospheric mantle beneath mid-ocean ridge and continent respectively, $\rho_{L}$ is density of lithospheric mantle. The values of these parameters are calculated by assuming an adiabatic gradient and considering temperature, compressibility and putative chemical depletion (see Supplementary Material for further details). We start by assuming lithospheric thinning is instantaneous such that the geotherm has not reached steady state. Our rationale is that most of the measurements considered indicate that uplift occurred on timescales shorter than lithospheric thermal time constants (e.g., $\tau=a^{2} / \pi^{2} \kappa ; \tau \approx 130$ Ma for $a=200 \mathrm{~km}, \kappa=10^{-6} \mathrm{~m}^{2} / \mathrm{s}$ ). Figure 9 shows how $e$ varies by changing $t_{c c}, \rho_{L}, \rho_{c a}$ and $a$. Results for steady geotherms are given as Supplementary Material. These calculations are used to examine the geodynamic evolution of lithosphere and asthenosphere beneath western North America and eastern South America. 


\section{Western North America}

Proposed mechanisms for uplift of the Colorado Plateau and surrounding regions include isostatic uplift from crustal thickening (e.g., Morgan and Swanberg, 1990; McQuarrie and Chase, 2000), mantle convection and shallow subduction of the Farallon slab (e.g., Moucha et al., 2008b; Liu and Gurnis, 2010), edge-driven convection (e.g., van Wijk et al., 2010), large-scale uplift by lithospheric thinning (Roberts et al., 2012; Bailey et al., 2012) or a combination of such processes (e.g., Levander et al., 2011). We make use of the inventory of uplift constraints and simple isostatic calculations to assess the contribution of changing lithosphere thicknesses, densities, and asthenospheric thermal anomalies.

Crustal thicknesses beneath the Rocky Mountains and the Great Plains are broadly similar, ranging from 36-43 km with a mean of $40 \mathrm{~km}$ (Figure 8; Buehler and Shearer, 2016). Conversion of shear wave tomographic models into temperature indicates that the lithosphere beneath the Great Plains (e.g., Minnesota, Iowa) is $\sim 200 \mathrm{~km}$ thick (Priestley and McKenzie, 2013). Solving Equation 5 using this value, a crustal thickness of $40 \mathrm{~km}$ and assuming that the plate rests directly upon asthenosphere that does not have excess temperature anomalies yields an elevation of $480 \mathrm{~m}$. This value is consistent with the average present-day elevation of the plains (Figure 9e: red box labeled GP). However, the distribution of Cretaceous marine rock across the plains, and paleo-water depth assessments from the PBDB indicate that most of the region was at or below current sea level by as much as $\sim 100 \mathrm{~m}$ (Figure 9e). This paleogeography is well known and used as a basis to parameterize geodynamic models of drawdown, which are often related to subduction of the Farallon Slab (e.g., Liu and Nummedal, 2004; Flament et al., 2013). If we assume that dynamic stresses and lithospheric thickness have not changed since the Cretaceous Period, we can explore an alternative explanation where the asthenosphere directly beneath the plate was cooler than it is today. For example, a $200 \mathrm{~km}$ thick asthenospheric layer that has an excess temperature of -74 to $-89^{\circ} \mathrm{C}$ yields elevations of 0 to $100 \mathrm{~m}$ below modern sea level. Increasing or decreasing the thickness of the layer adjusts estimated temperatures in a straightforward curvilinear way (e.g., Figure 9).

Causes for differential uplift between the Rocky Mountains and the Great Plains can be explored by considering the effects of lithospheric thinning and asthenospheric thermal anomalies (Figure 9e). We estimate the amount of lithospheric thinning beneath the Rocky Mountains by comparing its present-day thickness to thicknesses beneath the Great Plains. Figure 8a shows that conversion of shear wave tomography into estimates of lithospheric thicknesses indicates a difference of $\sim 150 \mathrm{~km}$. Inverse modeling of rare earth, major and trace elements from basalts across the plateau suggests that the average potential temperature of the asthenosphere beneath western North America is currently $1340 \pm 20^{\circ} \mathrm{C}$. The highest values $\left(\sim 1365{ }^{\circ} \mathrm{C}\right)$ are beneath the Snake River Plain, which implies excess temperatures of 0 to $45^{\circ} \mathrm{C}$ (Klöcking et al., 2018a). These measurements predict that the asthenosphere and lithosphere support almost all of the present-day elevation of the Southern Rocky Mountains ( $3.1 \mathrm{~km}$; red box, RM; Figure 9e). Using these values and Equation 5 we suggest that Late Cretaceous-Recent uplift of the Southern Rocky Mountains can be explained by an average increase in asthenospheric temperatures of $\sim 200{ }^{\circ} \mathrm{C}$ and $150 \mathrm{~km}$ of lithospheric thinning (red arrows, Figure 9e). In other words, we suggest that post-Cretaceous uplift of the Rocky-Mountains-Colorado-plateaus was a result of heating of the asthenosphere that was anomalously cool during Cretaceous times to its current anomalously warm state, and thinning of the plate beneath the region. These results are consistent with interpretations of major and trace element chemistry of basaltic rock from across the region (Klöcking et al., 2018a).

\section{Borborema}

Late Cretaceous shallow marine rock in the Araripe Plateau and basins along the Atlantic margin record $\sim 700 \mathrm{~m}$ of differential uplift on a length scale of $\sim 900-1000 \mathrm{~km}$ (Figure 7 ). Shear-wave-to-temperature conversions indicate that the lithosphere beneath the Araripe Plateau is $\sim 150 \mathrm{~km}$ thick, and thins to less than $100 \mathrm{~km}$ at the coast (Priestley and McKenzie, 2013). In contrast, inverse modeling of magnetotelluric data has been used to suggest that the lithosphere beneath the Araripe Plateau is $\sim 120 \mathrm{~km}$ thick, and surrounding lithosphere is as thick as $\sim 200 \mathrm{~km}$ (Garcia et al., 2019). H- $\kappa$ stacking of receiver functions in the Borborema Province indicates that crustal thicknesses are variable (30-41 $\pm 2 \mathrm{~km}$; Luz et al., 2015a). They are as low 
as $30 \mathrm{~km}$ in the Potiguar and Sergipe-Alagoas Basins, $38 \mathrm{~km}$ on the eastern edge of the Araripe Basin and $40 \mathrm{~km}$ within the Borborema Plateau. Luz et al. (2015b) suggest that p-wave velocities, $V_{p}$, of the upper and lower crust beneath the Borborema plateau are $6.03-7.33 \mathrm{~km} \mathrm{~s}^{-1}$. Conversion of these $V_{p}$ values into density suggests crustal densities of $2.73-2.91 \mathrm{Mg} \mathrm{m}^{-3}$ (Barton, 1986). Inserting these values into Equation 5 indicates that present-day lithospheric and crustal thicknesses (150 and $38 \mathrm{~km}$, respectively) are sufficient to explain the elevation of the Araripe Plateau without recourse to excess temperature anomalies in the asthenosphere.

A remaining question is why were significant tracts of the province marine in the Cretaceous Period? By Late Aptian times rift basins had developed along the Atlantic margin of the South American plate and within the continental interior (e.g., Machado Júnior et al., 1990; de Matos, 1992). Morais Neto et al. (2009) use thermal modeling of apatite fission track data to suggest two phases of exhumation of the Borborema Plateau, during Cenomanian-Turonian and Miocene times. Their results are broadly consistent with the transition from marine to fluvial depositional environments in the Araripe, Tucano and Jatobá basins, and the presence of the marine Miocene Barreiras Formation that crops out at higher elevations along the coast (Figure 7; Rossetti et al., 2013). Suggested mechanisms for Late Cretaceous to Recent uplift of the Borborema Plateau and Araripe Basin include crustal thickening by lateral flow related to Mesozoic rifting and mafic underplating driven by a deep mantle plume (Morais Neto et al., 2009), emplacement of a shallow upper mantle thermal anomaly (Ussami et al., 1999), localized mantle plume (Jardim de Sá et al., 1999), mafic underplating (Oliveira and Medeiros, 2012), basin inversion caused by plate-wide compression (Marques et al., 2014), and a modest, positive, asthenospheric thermal anomaly that has thinned the overlying lithosphere (Klöcking et al., 2020).

We note that Late Cretaceous marine rock that outcrops near the top of the Araripe Plateau was probably deposited after rifting. Interpreted paleo-water depths of the Santana Formation are $<50 \mathrm{~m}$, and the formation crops out at an elevation of 600-850 m. We tentatively suggest that one way of explaining observed vertical motions is that the asthenosphere beneath the Araripe Plateau was cooler in Cretaceous times than it is today. For example, warming of asthenosphere by $155^{\circ} \mathrm{C}$ to ambient $\left(1330 \pm 15{ }^{\circ} \mathrm{C}\right)$ temperatures yields $995 \pm 95 \mathrm{~m}$ of uplift (Equation 5). These results are consistent with Klöcking et al. (2018b, 2020) who, based on forward and inverse modeling of major, trace and rare earth element concentrations of volcanic samples, suggest a mantle potential temperature of $\sim 1320-1340{ }^{\circ} \mathrm{C}$. Alternatively, removal of $\sim 100 \mathrm{~km}$ of lithospheric mantle beneath the plateau can generate observed uplift. We note if the geotherm is at steady state $\sim 50 \mathrm{~km}$ of thinning is required (see Supplementary Material).

\section{Remarks on limitations and further work}

There are two main shortcomings in this study. The first is that we measured net uplift. Changes in uplift or subsidence rates, between marine deposition and their modern elevations, are not straightforwardly constrained using these observations. Histories of uplift can of course be refined using multiple observations of marine rock of different ages in the same or similar locations. Second, although the inventory of uplift measurements is reasonably dense in some places, there are clearly large gaps especially in continental interiors, most notably in Africa, central South America, northeastern Eurasia, and central Australia. These gaps represent a lack of marine deposition in some places. However, in others they are simply a manifestation of a partial inventory that can be improved by further work.

An obvious way to improve the inventory is inclusion of more documented marine rock. Another is addition of uplift and subsidence estimates generated using alternative approaches, for example, isotopic altimetry. We feel it is important to make a distinction between such estimates and the more direct, typically less equivocal, constraints provided by uplifted marine rock. A general challenge is designing sensible schemes to interpolate between spot measurements of uplift, subsidence and denudation. Attempts to do so have included interpolation of interpreted paleoenvironments and tectonic histories provided by geological observations (e.g., Sahagian, 1987; Scotese and Golonka, 1992; Carena et al., 2019; Markwick, 2019). For the Cenozoic Era, a useful approach is to make use of inverse modeling of drainage patterns. This approach provides a quantitative means for filling in spatio-temporal gaps between spot measurements of uplift and denudation, and is testable using inventories of uplift such as those generated in this study (e.g., Fernandes et al., 2019). 


\section{CONCLUSION}

This study generated an inventory of 24,372 measurements of Cretaceous to Recent net uplift. The inventory includes measurements in all continents and many ocean islands. The measurements were generated by combining records of Cretaceous to Recent marine rock in the Paleobiology Database (PBDB) with estimates of elevation, paleobathymetry, compaction, and global sea-level change. In some places the inventory is sufficiently dense that wavelengths and amplitudes of regional uplift can be constrained (e.g., western North America; Figure 10a-c). In other places sparse measurements provide useful bounds on topographic evolution (e.g., Borborema province, Brazil; Figure 10d-f). Less than $1 \%$ of the records in the PBDB required manual modification to correct erroneously located samples. A larger effort was required to check the quality of paleo-water depth and paleoenvironment records. We have attempted to correct or remove all points that are obviously erroneous and recommend careful checking of points in regions of interest. We combine points from western North America and the Borborema province with seismological observations and simple isostatic calculations to investigate the origins of topography. In these regions post-Cretaceous net uplift has amplitudes up to $\sim 1 \mathrm{~km}$ at wavelengths of $100-1000 \mathrm{~km}$. The results indicate that spot measurements of uplifted marine rock aid understanding of sub-continental mantle dynamics and mantle-surface interactions. The inventory of uplift measurements might also provide useful constraints on paleo-environmental, -climatic and -biologic evolution.

\section{Acknowledgments}

We thank all contributors to the Paleobiology Database and A. Boyce, N. Flament, G. Hampson, A. Lipp, C. O'Malley, F. Richards, D. Sahagian, A. Whittaker and three anonymous reviewers for their helpful comments and discussion. Data Repository items are available online at www.geosociety.org/pubs/ft20XX.htm, or on request from editing@geosociety.org.

GSA Data Repository item 201Xxxx. 


\section{FIGURES}
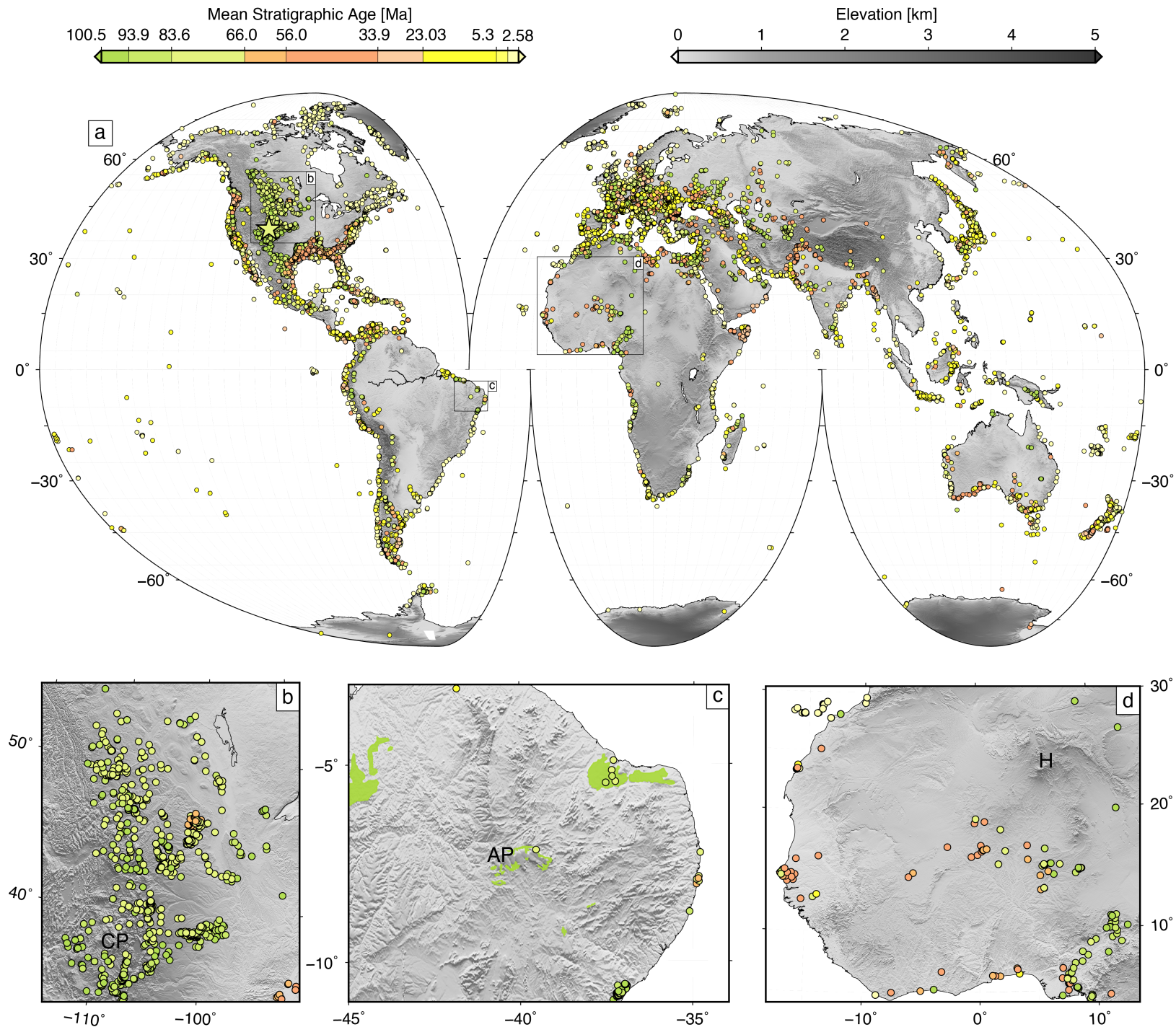

Figure 1: Paleobiology inventory. (a) Circles = Cretaceous to Recent marine fossils contained within the Paleobiology Database (PBDB) used to measure uplift; colors indicate mean stratigraphic age. Gray scale = hill-shaded topography $($ ETOPO1). Star (central western North America) = location of example shown in Figure 3. (b/c/d) Distribution of uplift constraints in western North America/Borborema Province, Brazil/NW Africa. $\mathrm{CP}=$ Colorado Plateau, AP $=$ Araripe Plateau, $\mathrm{H}=$ Hoggar Mountains. Green polygons in panel (c) show distribution of Cretaceous marine rock including the Araripe Plateau, which is shown in the center of the panel. 


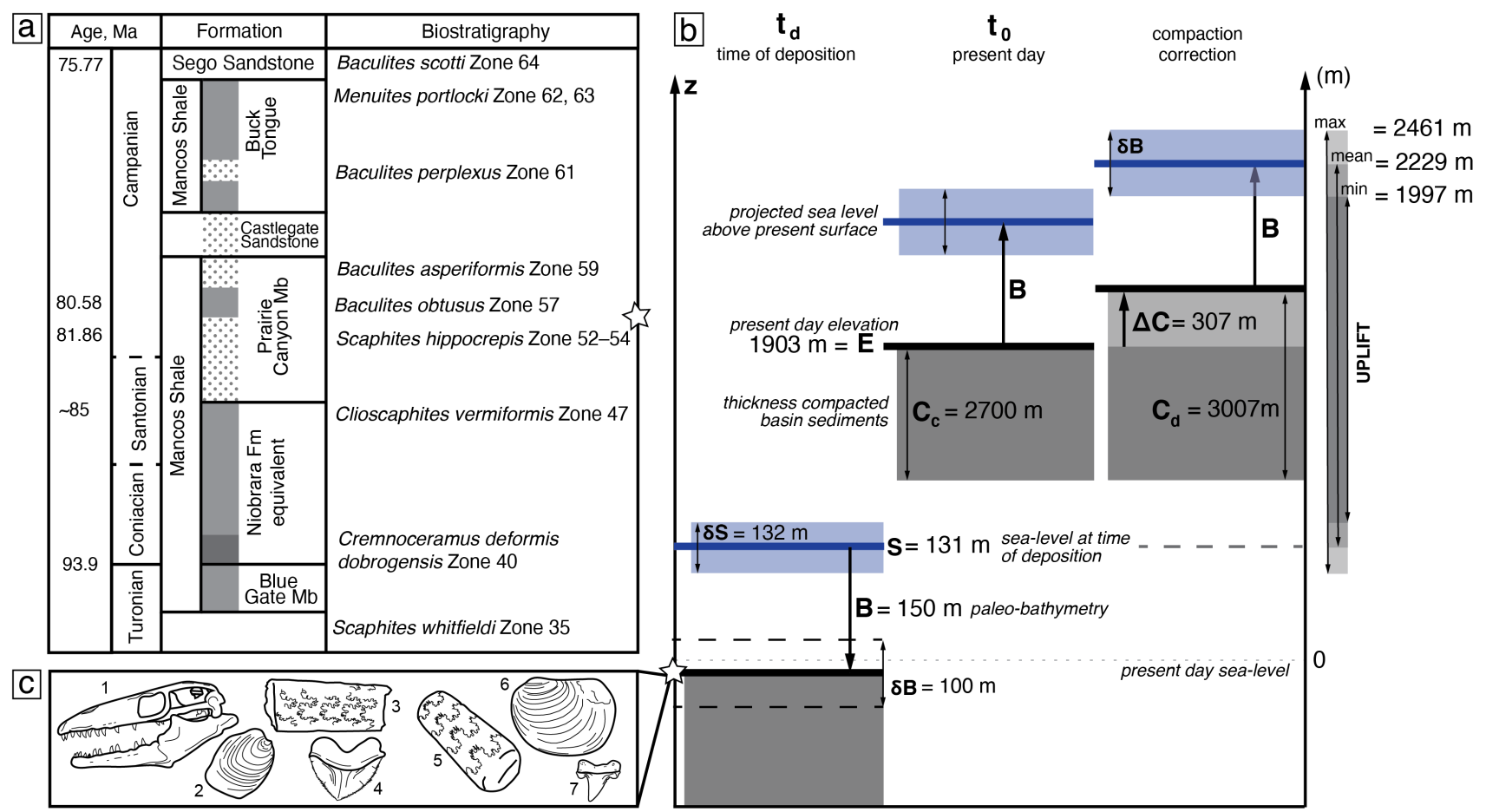

Figure 2: Schematic illustrating methodology to calculate uplift. (a) Generalized stratigraphic column of Mancos Shale successions in western Colorado (see star in Figure 1a). Age constraint is based upon ammonite zones (see Biostratigraphy pane) and radiometric dating in some places (Obradovich and Cobban, 1975; Merewether and McKinney, 2015); dotted/light/dark gray bars = sand/sandy-shale/shale. Star = location of fossil assemblage shown in panel (c). (b) Schematic diagram shows information used to calculate uplift and its uncertainty. Gray $=$ solid Earth and associated compaction $(\Delta C)$ and paleobathymetric $(B)$ corrections; blue $=$ sea-level correction. (c) Fossil assemblage used to constrain age and paleoenvironment of Prairie Canyon Member of the Mancos Shale (see star in panel a) from PBDB: 1-Prognathodon [mosasaur], 2-Platyceramus cycloides [bivalve], 3-Baculites haresi [ammonite], 4-Squalicorax pristodontus [shark], 5-Baculites aquilaensis [ammonite], 6-Innoceramus balticus [bivalve], 7-Cretolamna [shark]. 


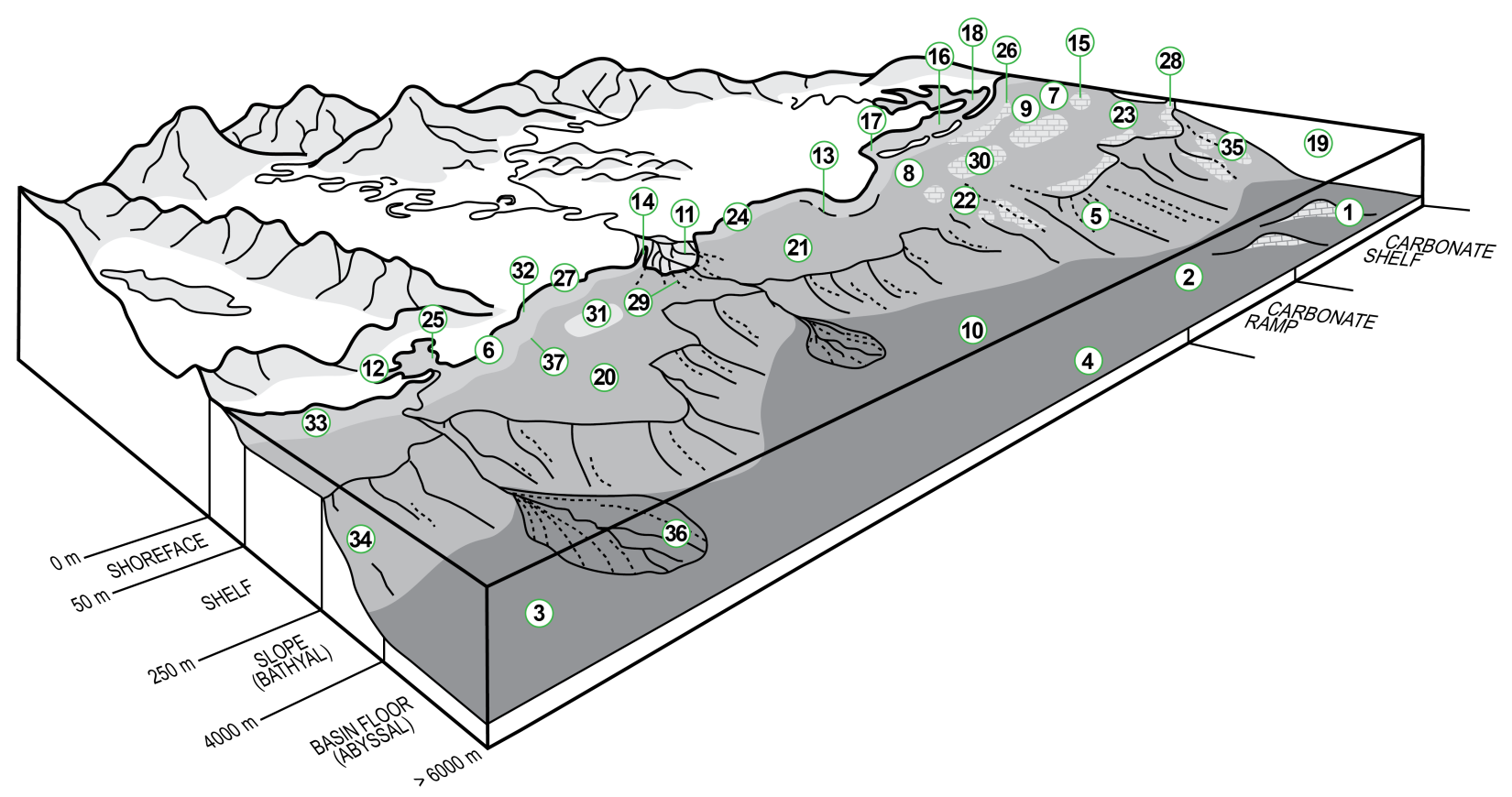

Figure 3: Bathymetric model. Cartoon illustrates the distribution of marine paleoenvironments recorded in the PBDB. 1-basin reef, 2-basinal (carbonate), 3-basinal (siliciclastic), 4-basinal (siliceous), 5-carbonate indet., 6-coastal indet., 7-deep subtidal, 8-deep subtidal ramp, 9-deep subtidal shelf, 10-deep-water indet., 11-delta front, 12-estuary/bay, 13-foreshore, 14-interdistributary bay, 15-intrashelf/intraplatform reef, 16lagoonal/restricted shallow subtidal, 17-lagoonal, 18-marginal marine indet., 19-marine indet., 20-offshore, 21-offshore indet., 22-offshore ramp, 23-offshore shelf, 24-open shallow subtidal, 25-paralic indet., 26-perireef or subreef, 27-peritidal, 28-platform/shelf-margin reef, 29-prodelta, 30-reef, buildup or bioherm, 31-sand shoal, 32-shallow subtidal indet., 33-shoreface, 34-slope, 35-slope/ramp reef, 36-submarine fan, 37-transition zone/lower shoreface. Depths are given for illustrative purposes; description of paleoenvironments is given in Table 1. 


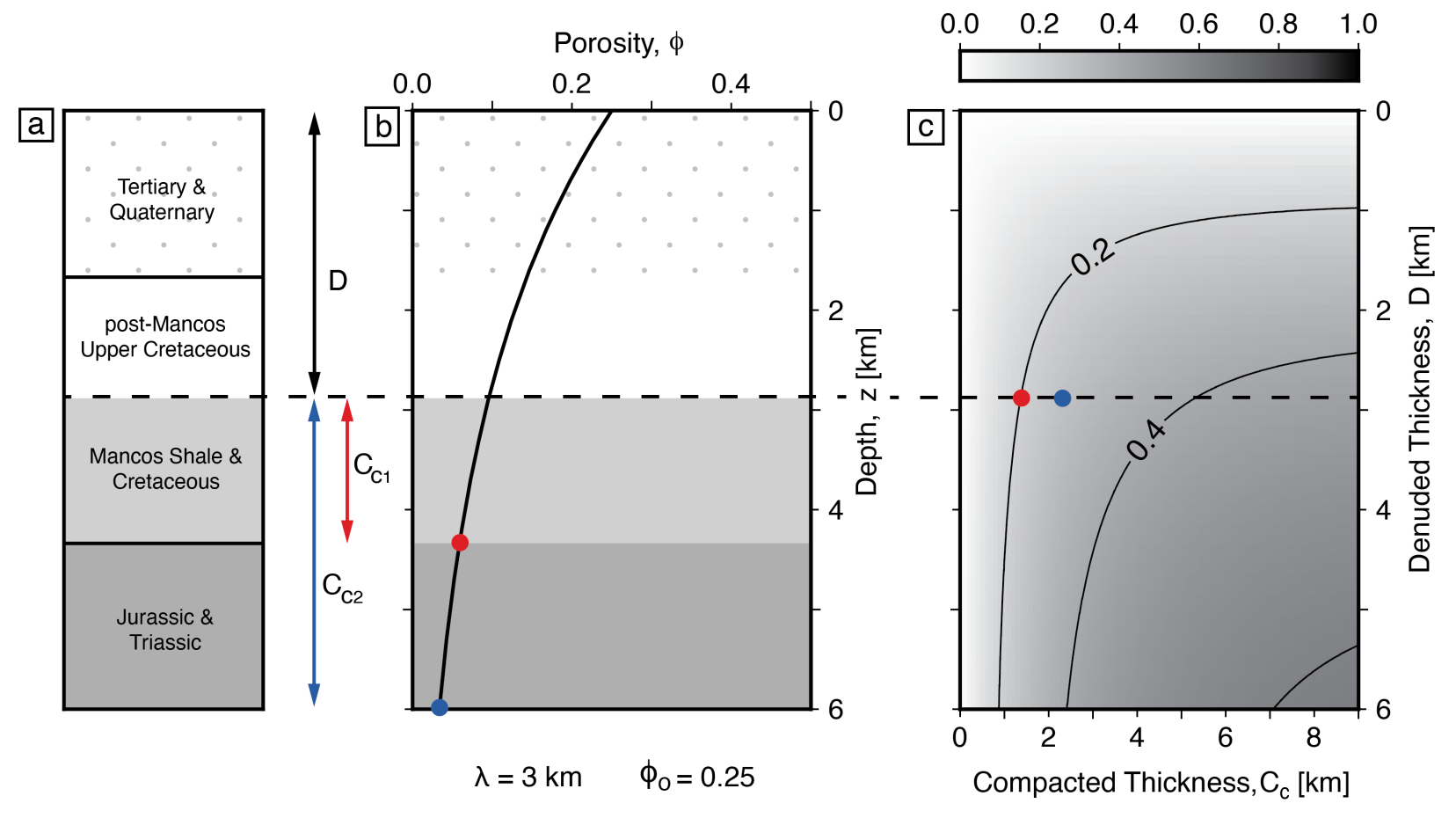

Figure 4: Compaction correction. Panels show calculated elevation change from decompacting rock beneath the sample (dashed line), $C_{c}$, and denudation of overlying rock, $D$. (a) Generalized stratigraphy of western North American example (see star in Figures 1a and 3). $C_{c 1}$ is thickness of Cretaceous sedimentary rock beneath Prarie Canyon Member of the Mancos Shale $\left(C_{c 1}=1.4 \mathrm{~km}\right), C_{c 2}$ is thickness of Triassic to Cretaceous rock beneath Prarie Canyon Member $\left(C_{c 2}=2.7 \mathrm{~km}\right)$; thicknesses were estimated from composite stratigraphic logs (Hintze and Kowallis, 2009). (b) Black curve = porosity-depth function for the Piceance Basin calculated by fitting porosity-depth data from well logs (see Equation 2); initial porosity $\phi_{\circ}=0.25$, compaction wavelength $\lambda=3 \mathrm{~km}$ (Chapman et al., 1984). (c) Gray scale and contours show uplift correction, $\Delta C$, following decompaction. For this example decompacting only $C_{c 1}$ yields $0.21 \mathrm{~km}$ of additional uplift (red circle), and $0.31 \mathrm{~km}$ when $C_{c 2}$ is decompacted (blue circle). 

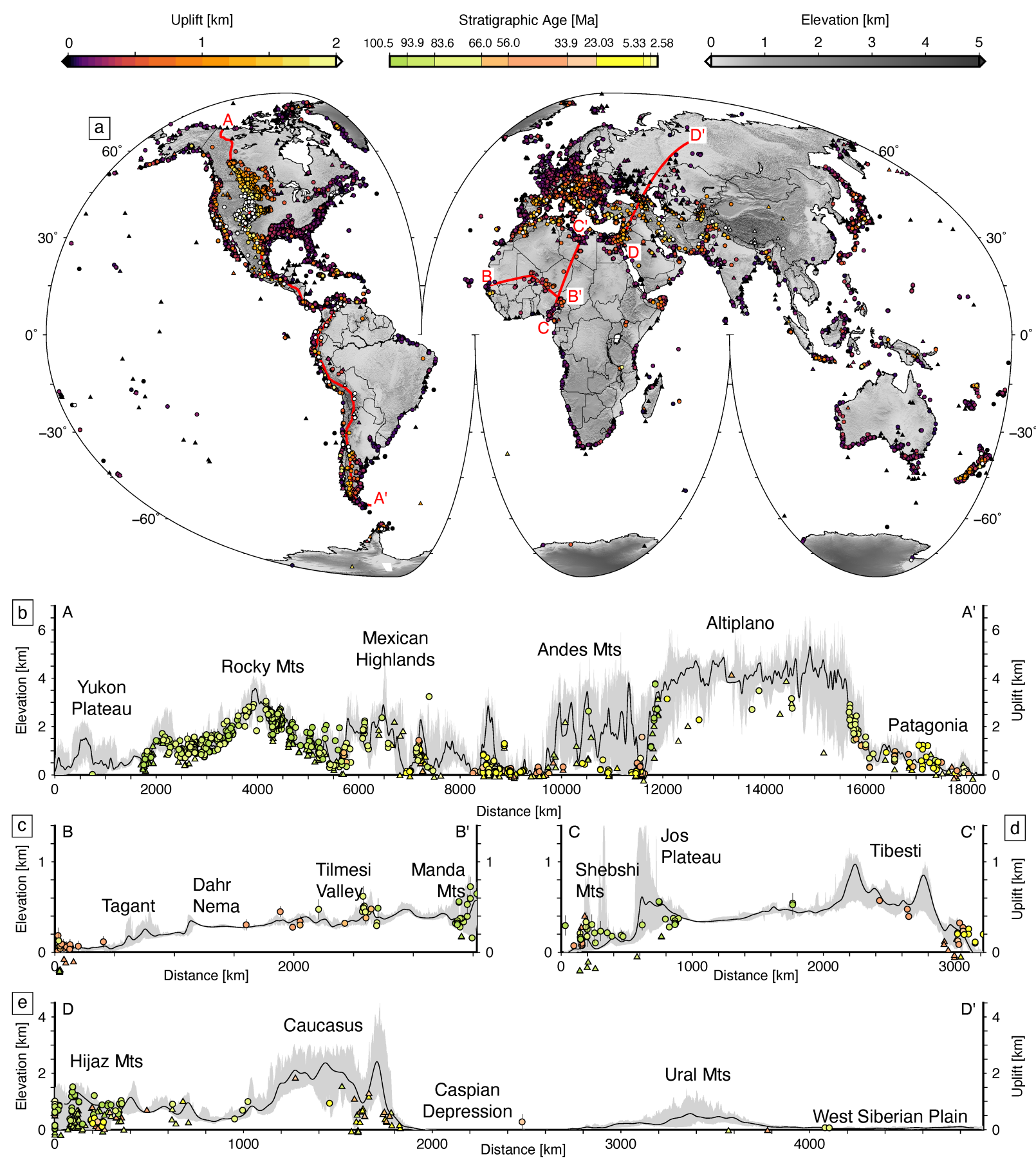

Figure 5: Global measurements of uplift. (a) Circles/triangles = accurate/minimum uplift measurements generated using the PBDB. Curves labeled $A-A^{\prime}, B-B^{\prime}, C-C^{\prime}$ and $D^{-} D^{\prime}$ are locations of swaths shown in panels (b-e). (b) Circles/triangles = uplift constraints within $100 \mathrm{~km}$ wide swath through North, Central and Southern America; colors = mean stratigraphic age. Major provinces are labeled. Black curve $=$ topography along center of transect; gray polygon $=$ extreme topography within swath. (c/d/e) Cross sections through northwest Africa/North Africa/Middle East and Eurasia. 

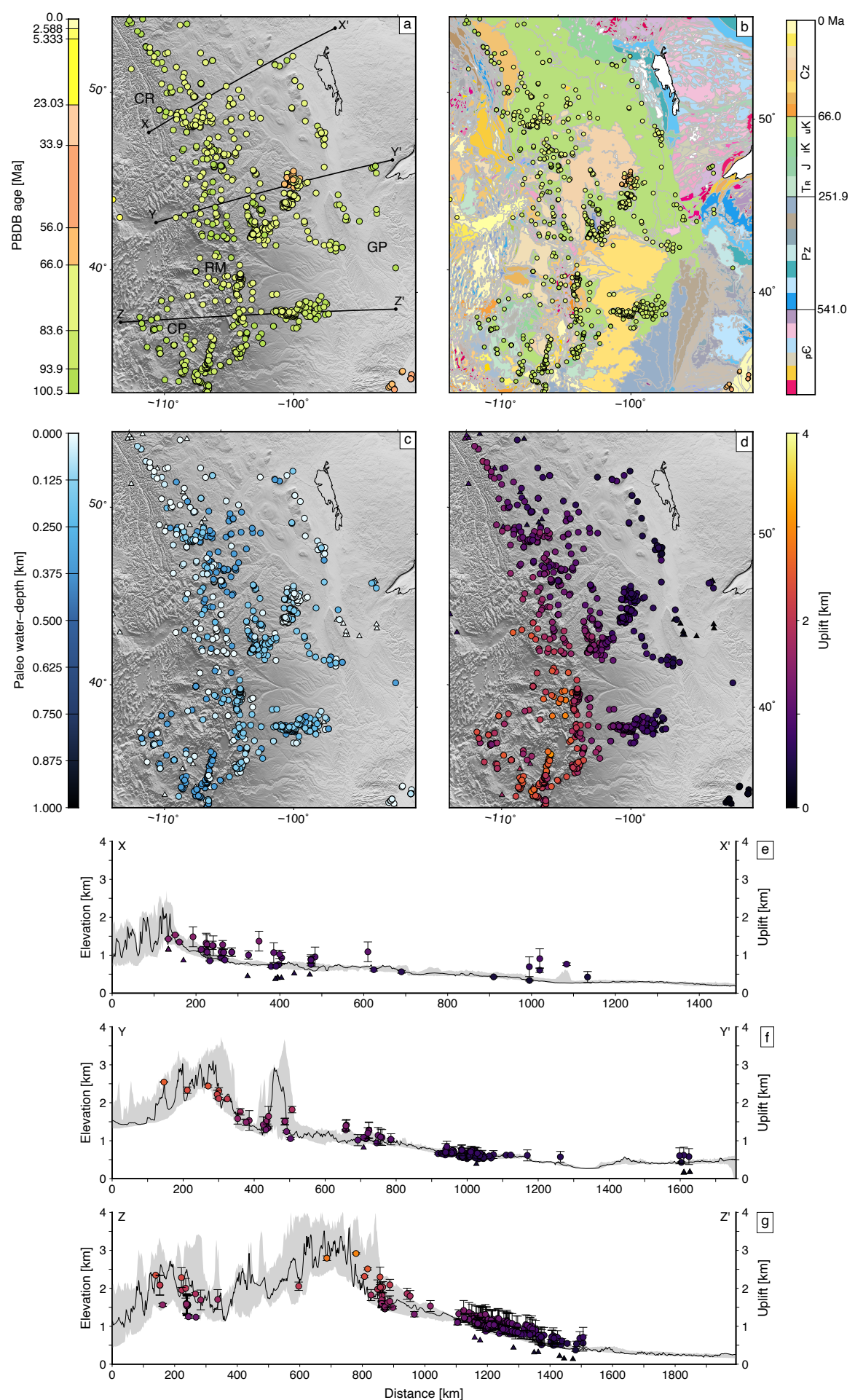

Figure 6: Uplift of Western Interior of North America. (a) Circles $=$ PBDB measurements colored by mean stratigraphic age; gray scale $=$ hill-shaded topography (ETOPO1); $C R=$ Canadian Rockies, $G P=$ Great Plains, $\mathrm{RM}=$ Rocky Mountains, $\mathrm{CP}=$ Colorado Plateau. See Figure 1a for location. $\mathrm{X}-\mathrm{X}^{\prime}, \mathrm{Y}-\mathrm{Y}^{\prime}, \mathrm{Z}-\mathrm{Z}^{\prime}$ $=$ cross sections shown in panels $(\mathrm{e}-\mathrm{g})$. (b) PBDB measurements overlaid on 1:1M geological map of North America (Reed et al., 2005, see original publication for full key and unit descriptions); $\mathrm{p} \in=$ PreCambrian, $\mathrm{Pz}$ $=$ Paleozoic, $\operatorname{Tr} / \mathrm{J} / \mathrm{IK} / \mathrm{uK}=$ Triassic/Jurassic/lower Cretaceous/upper Cretaceous, $\mathrm{Cz}=$ Cenozoic. (c) Mean paleobathymetry from PBDB inventory. (d) Mean net uplift since time of deposition from PBDB measurements. (e-g) Cross sections $X-X^{\prime}, Y-Y^{\prime}, Z-Z^{\prime}$ : gray bands = topography within $100 \mathrm{~km}$ wide swath of central cross section (black curves); circles/triangles $=$ mean/minimum uplift from measurements within swath; error bars $=$ full range of paleobathymetry uncertainties. 

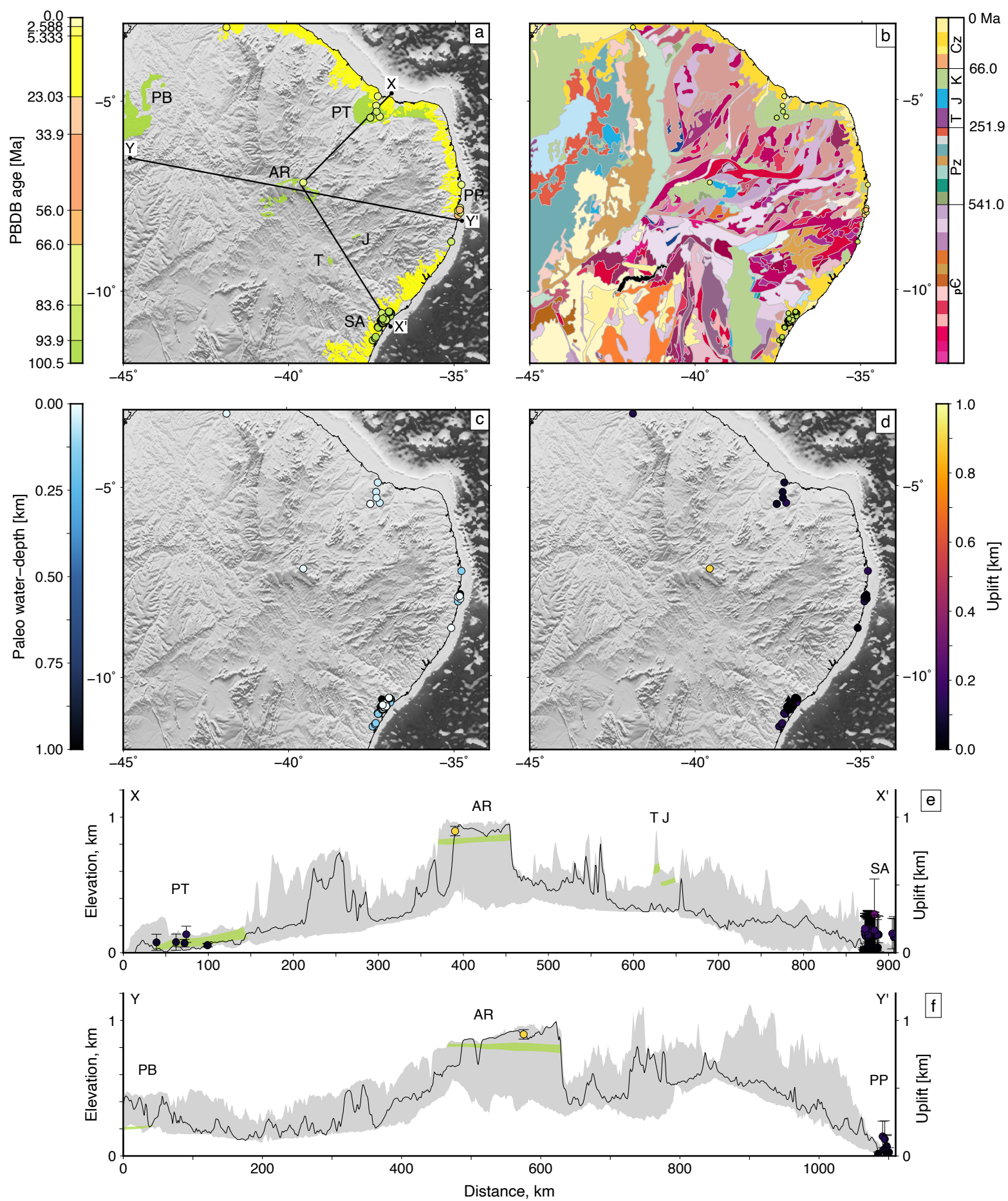

Figure 7: Uplift of the Borborema Plateau, NE Brazil. (a) PBDB measurements coloured by mean stratigraphic age atop hill-shaded topography (ETOPO1); See Figure 1a for location. AR = Araripe Plateau, $\mathrm{PT}=$ Potiguar, $\mathrm{PP}=$ Pernambuco-Paraíba, $\mathrm{SA}=$ Sergipe-Alagoas, $\mathrm{T}=$ Tucano, $\mathrm{J}=$ Jatobá, $\mathrm{PB}=$ Parnaíba basins. Green polygons show location of exposed marine rock of the Santana Formation within the Araripe and Tucano-Jatobá basins (Custódio et al., 2017). Yellow polygons = Miocene marine Pirabas and Barreiras Formations (Rossetti et al., 2013). Cross sections $X-X^{\prime}$ and $Y-Y^{\prime}$ are shown in panels (e-f). (b) 1:5M geological map (Gómez et al., 2018). (c-d) Paleobathymetry and mean post-deposition uplift from PBDB measurements. (e-f) Cross sections $\mathrm{X}-\mathrm{X}^{\prime}$ and $\mathrm{Y}-\mathrm{Y}^{\prime}$ : Topography from ETOPO1 along cross sections (black curves) and within $100 \mathrm{~km}$ wide swaths (gray band); coloured circles with error bars = measurements of mean uplift and paleobathymetric uncertainties within the swaths. Green bands show elevation of (Cretaceous, marine) Santana, Codó and Jandaíra Formations projected onto cross section. 

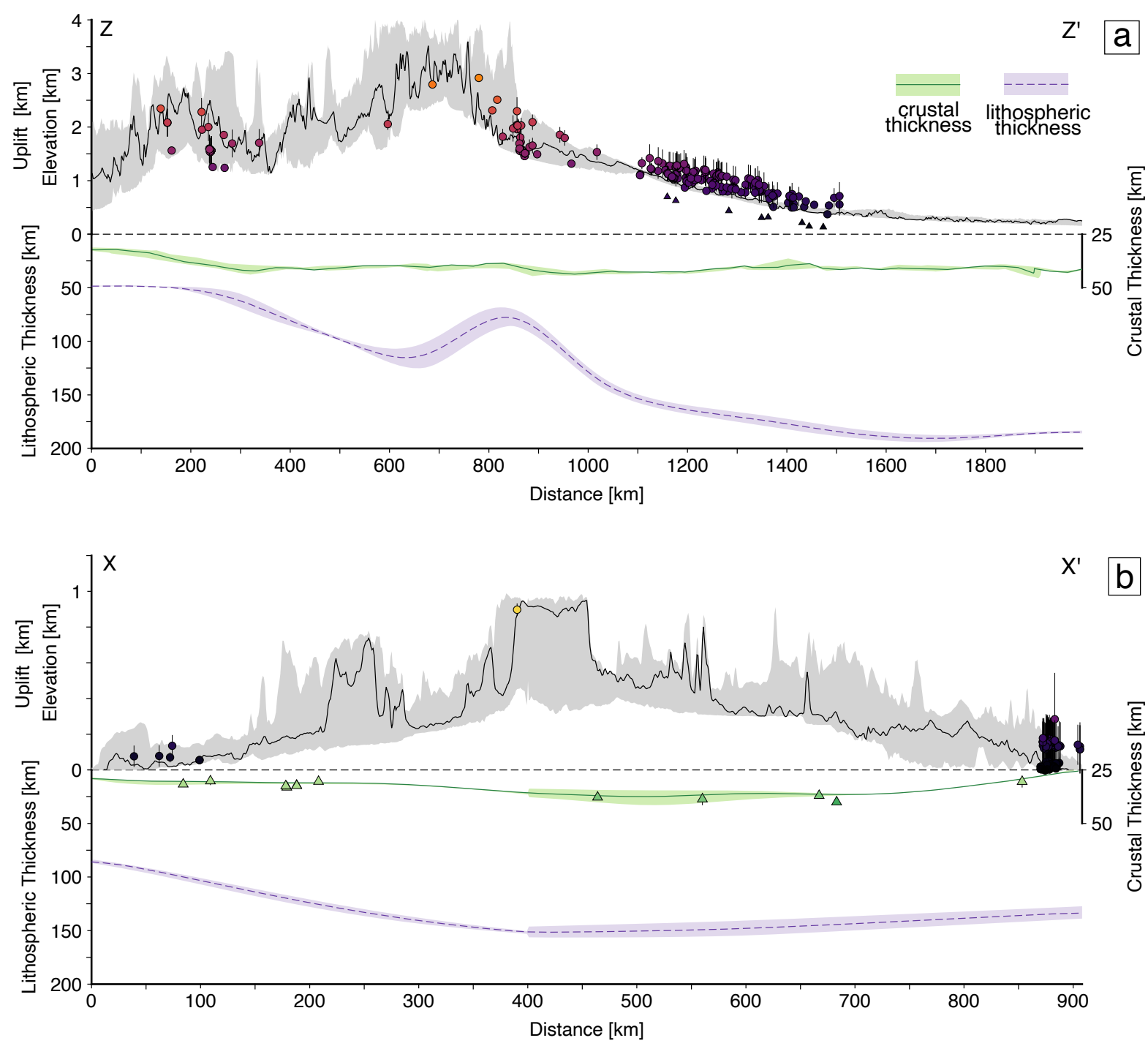

Figure 8: Cross sections through uplift and geophysical measurements. (a) Cross section through western North America (see Figure 6: Z-Z'; color scale) showing crustal thickness from $P n$-wave tomography and lithospheric thickness generated by converting a shear wave tomographic model into temperature (Priestley and McKenzie, 2013; Buehler and Shearer, 2016). (b) Cross section across Borborema province (see Figure 7: X-X'; color scale ) showing crustal thickness from CRUST1.0 and Moho depths from H- $\kappa$ stacks of P-to-S receiver functions (triangles) and lithospheric thickness (Laske et al., 2013; Luz et al., 2015a). 

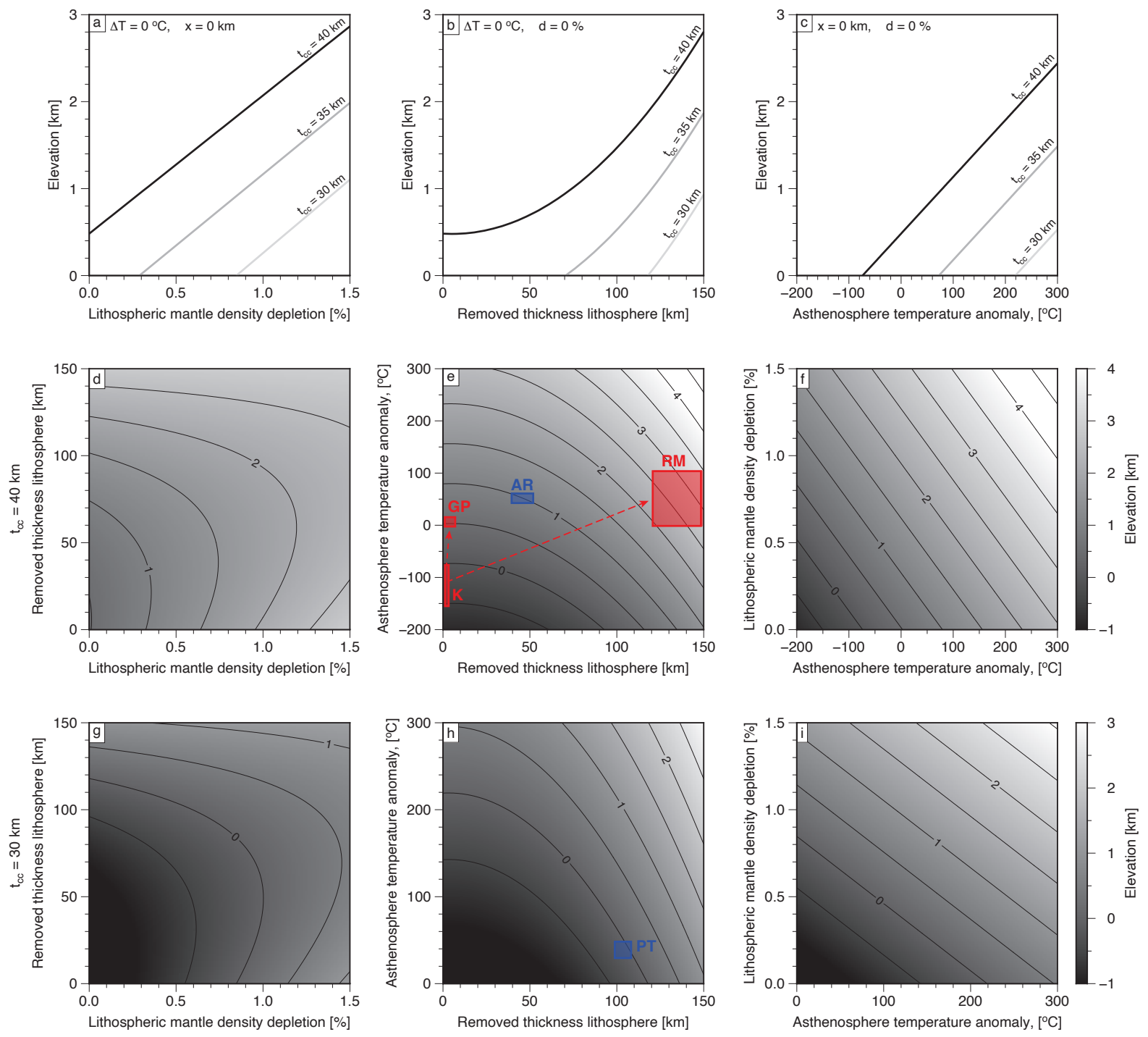

Figure 9: Parameterization of isostatic calculations. Top row shows predicted elevation as a function of crustal thickness, $t_{c c}$, and (a) \% depletion, $d$, (density) of lithospheric mantle; (b) removed thickness of lithospheric mantle, $x$; (c) asthenospheric temperature anomalies, $\Delta T$. Middle row: Gray scale and contours show calculated elevations for a crustal thickness of $40 \mathrm{~km}$ and (d) depletion and thinning of the lithosphere, (e) lithospheric thinning and asthenospheric temperature anomalies, and (f) asthenospheric temperature anomalies and mantle depletion. (g)-(i) Predicted elevations for a crustal thickness of $30 \mathrm{~km}$. Labeled boxes indicate estimates of support for Cretaceous western interior of North America (K), Great Plains (GP), Araripe Plateau (AR), Rocky Mountains (RM) and Potiguar Basin (PT). 


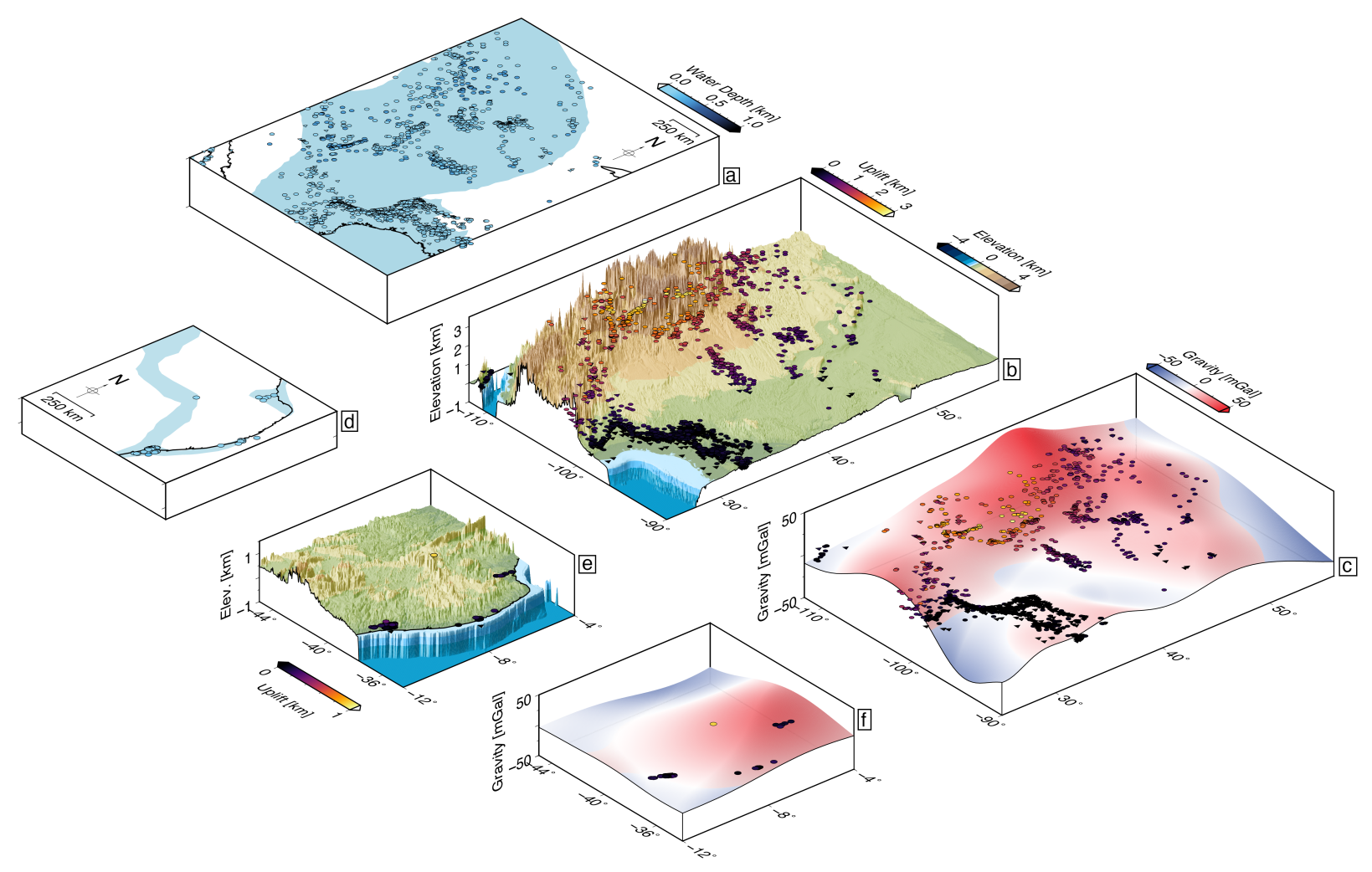

Figure 10: Schematic paleogeographies and uplift patterns from PBDB measurements. (a) Cretaceous paleogeography of western North America. Colored circles = paleobathymetry from PBDB measurements; blue polygon $=$ Turonian $(\sim 98 \mathrm{Ma}$ ) seaway (Heine et al., 2015). (b) Modern topography (ETOPO1) overlaid with measured uplift points (colored circles). (c) Uplift (colored circles) atop long-wavelength $(\sim 800-2500 \mathrm{~km})$ free-air gravity (GRACE). (d-f) Paleogeography, uplift and sub-plate support of Borborema province, NW Brazil. Blue polygons in panel (d) indicate late Albian ( 100.5 Ma) paleocoastline (Arai, 2009). 


\section{References}

Aciego, S. M., DePaolo, D. J., Kennedy, B. M., Lamb, M. P., Sims, K. W., and Dietrich, W. E., 2007, Combining ${ }^{3} \mathrm{He}$ cosmogenic dating with $\mathrm{U}-\mathrm{Th} / \mathrm{He}$ eruption ages using olivine in basalt: Earth and Planetary Science Letters, v. 254(3-4), p. 288-302, doi:10.1016/j.epsl.2006.11.039.

Amante, C., and Eakins, B. W., 2009, ETOPO1 1 Arc-minute global relief model: procedures, data sources and analysis: NOAA Technical Memorandum NESDIS NGDC-24, National Geophysical Data Center, NOAA, no. 10, V5C8276M.

Anderson, R. S., and S. P. Anderson, 2010, Geomorphology: The mechanics and chemistry of landscapes: Cambridge University Press.

Antonioli, L., Thiago, L. K., Rodrigues, M. A. C, and Dino, R., 1999, Análise palinoestratigráfica dos sedimentos Aptianos da Bacia do Parnaíba, aflorantes na região de Codó, MA: Boletim de Resumos do Congresso Brasileiro de Paleontologia, Abstracts, v. 16, p. 18-19.

Arai, M., and Coimbra, J. C., 1990, Análise paleoecológica do registro das primeiras ingressões marinhas na Formação Santana (Cretáceo Inferior da Chapada do Araripe): $1^{\circ}$ Simpósio da Bacia do Araripe e Bacias Interiores do Nordeste - Atas. SBG, Crato-CE, Brazil, p. 225-240.

Arai, M., 2009, Paleogeografia do Atlântico Sul no Aptiano: um novo modelo a partir de dados micropaleontológicos recentes, Boletim de Geociências - Petrobras, v. 17 no. 2, p. 331-351.

Arthur, M. A., and Sageman, B. B., 2004, Sea-level control on source-rock development: Perspectives from the Holocene Black Sea, the Mid-Cretaceous Western Interior Basin of North America, and the Late Devonian Appalachian Basin, SEPM Special Publication, v. 82, p. 35-59.

Athy, L F., 1930, Density, porosity, and compaction of sedimentary rocks, AAPG Bulletin, v. 14 no. 1, p. 1-24.

Assine, M. L., 1994, Paleocorrentes e paleogeografia da Bacia do Araripe, nordeste do Brasil, Revista Brasileira de Geociências, v. 24 no. 4, p. 223-232.

Assine, M. L., 2007, Bacia do Araripe, Boletim de Geociências da Petrobras, Rio de Janeiro, v. 15 no. 2, p. 371-389.

Audet, P., 2014, Toward mapping the effective elastic thickness of planetary lithospheres from a spherical wavelet analysis of gravity and topography, Physics of the Earth and Planetary Interiors, v. 226, p. 48-82, doi:10.1016/j.pepi.2013.09.011.

Austermann, J., Mitrovica, J. X., Huybers, P. and Rovere, A., 2017, Detection of a dynamic topography signal in last interglacial sea-level records, Science Advances, v. 3 no. 7, doi:10.1126/sciadv.1700457.

Barbosa, J. A., Neumann, V. H., Lima Filho, M., Souza, E. D., and Moraes, M. D., 2007, Estratigrafia da faixa costeira Recife-Natal (Bacia da Paraíba e Plataforma de Natal), NE Brasil, Estudos Geológicos, v. 17 no. 2, p. 3-30.

Bailey, I. W., Miller, M. S., Liu, K., and Levander, A., 2012, VS and density structure beneath the Colorado Plateau constrained by gravity anomalies and joint inversions of receiver function and phase velocity data, Journal of Geophysical Research - Solid Earth, v. 117(B2), doi:10.1029/2011JB008522

Barton, P. J., 1986, The relationship between seismic velocity and density in the continental crust-a useful constraint?, Geophysical Journal International, v. 87 no. 1, 195-208, doi:10.1111/j.1365-246X.1986.tb04553.x.

Berggren, W. A., 1974, Paleocene benthonic foraminiferal biostratigraphy, biogeography, and paleoecology of Libya and Mali, Micropaleontology, v. 20, p. 449-465.

Bessin, P., Guillocheau, F., Robin, C., Braun, J., Bauer, H., and Schroëtter, J., 2017, Quantification of vertical movement of low elevation topography combining a new compilation of global sea-level curves and scattered marine deposits (Armorican Massif, western France), Earth and Planetary Science Letters, v. 470, p. 25-36, doi:10.1016/j.epsl.2017.04.018.

Bétard, F., 2010, Uplift and denudation history at low-elevation passive margins: Insights from morphostratigraphic analysis in the SE Armorican Massif along the French Atlantic margin, Comptes Rendus Geoscience, v. 342, p. 215-222, doi:10.1016/j.crte.2010.02.004. 
Bierman, P., and Steig, E. J., 1996, Estimating rates of denudation using cosmogenic isotope abundances in sediment, Earth surface processes and landforms, v. 21 no. 2, 125-139, doi:10.1002/(SICI)1096-9837(199602)21:2<125::AIDESP $511>3.0 . \mathrm{CO} ; 2-8$

Bjerrum, C. J., and Dorsey, R. J., 1995, Tectonic controls on deposition of Middle Jurassic strata in a retroarc foreland basin, Utah-Idaho trough, western interior, United States, Tectonics, v. 14 no. 4, p. 962-978.

Boyden, J. A., et al. (eds.), 2011, Next-generation plate-tectonic reconstructions using GPlates, in Geoinformatics: Cyberinfrastructure for the Solid Earth Sciences, 95-113, Cambridge University Press, Cambridge, UK.

Buehler J. S., and Shearer, P. M., 2016, Uppermost mantle seismic velocity structure beneath USArray, Journal of Geophysical Research, v. 121, doi:10.1002/2016JB013265.

Burke, K., and Gunnell, Y., 2008, The African erosion surface: A continental-scale synthesis of geomorphology, tectonics, and environmental change over the past 180 million years, v. 201, Geological Society of America.

Carena, S., Bunge, H.-P. and Friedrich, A. M., 2019, Analysis of geological hiatus surfaces across Africa in the Cenozoic and Implications for the timescales of convectively-maintained topography, Canadian J. Earth Sciences, doi:10.1139/cjes-2018-0329.

Campos Neto, O. D. A., Lima, W. S., and Cruz, F. G., 2007, Bacia de Sergipe-Alagoas, Boletim de Geociências da Petrobras, v. 15 no. 2, p. 405-415.

Chamberlain, C. P., Mix, H. T., Mulch, A., Hren, M. T., Kent-Corson, M. L., Davis, S. J., Horton, T. W., and Graham, S. A., 2012, The Cenozoic climatic and topographic evolution of the western north American Cordillera, American Journal of Science, v. 312 no. 2, p. 213-262, doi:10.2475/02.2012.05.

Chapman, D. S., Keho, T. H., Bauer, M. S., and Picard, M. D., 1984, Heat flow in the Uinta Basin determined from bottom hole temperature (BHT) data, Geophysics, v. 49 no. 4, p. 453-466.

Coimbra, J. C., Arai, M., and Carreño, A. L., 2002, Biostratigraphy of Lower Cretaceous microfossils from the Araripe basin, northeastern Brazil, Geobios, v. 35, p. 687-698.

Cole, R. D., Young, R. G., and Willis, G. G., 1997, Prairie Canyon Member, a new unit of the Upper Cretaceous Mancos Shale, West-Central Colorado and East-Central Utah, Utah Geological Survey Miscellaneous Publications, v. 97 no. 4 , p. 23 .

Copley, A., and McKenzie, D., 2007, Models of crustal flow in the India-Asia collision zone, Geophysical Journal International, v. 169 no. 2, p. 683-698, doi:10.1111/j.1365-246X.2007.03343.x.

Cross, T. A., and Piliger, R. H., 1978, Tectonic controls of late Cretaceous sedimentation, western interior, USA, Nature, v. 247, p. 653-657.

Custódio, M. A., Quaglio, F., Warren, L. V., Simões, M. G., Fürsich, F. T., Perinotto, J. A. J., and Assine, M. L., 2017. The transgressive-regressive cycle of the Romualdo Formation (Araripe Basin): Sedimentary archive of the Early Cretaceous marine ingression in the interior of Northeast Brazil, Sedimentary Geology, v. 359, p. 1-15, doi:10.1016/j.sedgeo.2017.07.010.

Czarnota, K., Hoggard, M. J., White, N. and Winterbourne, J., 2013, Spatial and temporal patterns of Cenozoic dynamic topography around Australia, Geochemistry, Geophysics, Geosystems, v. 14 no. 3, doi:10.1029/2012GC004392.

Davis, W. M., 1899, The Geographical Cycle, Geographical Journal, v. 14 no. 5, p. 481-504, doi:10.1086/521238.

Dean, C. D., Collins, D. S., van Cappelle, M., Avdis, A., and Hampson, G. J., 2019, Regional-scale paleobathymetry controlled location, but not magnitude, of tidal dynamics in the Late Cretaceous Western Interior Seaway, USA, Geology, v. 47 no. 11, p. 1083-1087, doi:10.1130/G46624.1.

Densmore, A. L., and Hovius, N., 2000, Topographic fingerprints of bedrock landslides, Geology, v. 28 no. 4, p. 371-374, doi: $10.1130 / 0091-7613(2000) 28<371:$ TFOBL $>2.0 . \mathrm{CO} ; 2$.

Dorsey, R. J., Housen, B. A., Janecke, S. U., Fanning, C. M., and Spears, A. L. F., 2011, Stratigraphic record of basin development within the San Andreas fault system: Late Cenozoic Fish Creek - Vallecito basin, southern California, Geological Society of America Bulletin, v. 123 no. 5-6, p. 771-793, doi:10.1130/B30168.1. 
Dyman, T. S., Cobban, W. A., Fox, J. E., Hammond, R. H., Nichols, D. J., Perry Jr., W. J., Porter, K. W., Rice, D. D., Setterholm, D. R., Shurr, G. W., Tysdal, R. G., Harley, J. C., and Campen, E. B., 1994, Cretaceous frocks from Southwestern Montana to Southwestern Minnesota, Northern Rocky Mountains and Great Plains Region, in Shurr, G. W., Ludvigson, G. A., and Hammond, R. H. eds. Perspectives on the eastern margin of the Cretaceous Western Interior Basin, Geological Society of America, Special Paper 287.

Eicher, D. L., 1969, Paleobathymetry of Cretaceous Greenhorn sea in eastern Colorado, AAPG Bulletin, v. 53 no. 5 , p. 1075-1090, doi:10.1306/5D25C81B-16C1-11D7-8645000102C1865D.

Elliott, J. R., Walters, R. J. and Wright, T. J., 2016, The role of space-based observation in understanding and responding to active tectonics and earthquakes, Nature Communications, v. 7, 13844, doi:10.1038/ncomms13844.

England, P. and Molnar, P., 1990, Surface uplift, uplift of rocks, and exhumation of rocks, Geology, v. 18 no. 12 , p. $1173-1177$.

Ericksen, M. C., and Slingerland, R., 1990, Numerical simulations of tidal and wind-driven circulation in the Cretaceous Interior Seaway of North America, Geological Society of America Bulletin, v. 102 no. 11, p. 1499-1516, doi:10.1130/0016-7606(1990)102<1499:NSOTAW>2.3.CO;2.

Fernandes, V. M., Roberts, G. G., White, N., and Whittaker, A. C., 2019, Continental-Scale Landscape Evolution: A History of North American Topography, Journal of Geophysical Research - Earth Surface, v. 124 no. 11 , p. 2689-2722, doi:10.1029/2018JF004979.

Finnegan, N. J., Schumer, R., and Finnegan, S., 2014, A signature of transience in bedrock river incision rates over timescales of $10^{4}-10^{7}$ years, Nature, v. 505 no. 7483, p. 391-394, doi:10.1038/nature12913.

Flament, N., Gurnis, M., and Müller, R. D., 2013, A review of observations and models of dynamic topography, Lithosphere, v. 5 no. 2, p. 189-210.

Freitas, B. T., Almeida, R. P., Carrera, S. C., Figueiredo, F. T., Turra, B. B., Varejão, F. G. and Assine, M. L., 2017, Aptian sedimentation in the Recôncavo-Tucano-Jatobá Rift System and its tectonic and paleogeographic significance, Journal of South American Earth Science, v. 80, p. 460-481, doi:10.1016/j.sames.2017.10.001.

Gallagher, K., and Lambeck, K., 1989, Subsidence, Sedimentation and Sea-level Changes in the Eromanga Basin, Australia, Basin Research, v. 2, p. 115-131.

Galloway, W. E., T. L. Whiteaker and P. Ganey-Curry, 2011, History of Cenozoic North American drainage basin evolution, sediment yield, and accumulation in the Gulf of Mexico basin, Geosphere, v. 7 no. 4, p. 938-973, doi:10.1130/GES00647.1.

Gani, R. M., Ranson, A., Cross, D. B., Hampson, G. J., Gani, N. D. and Sahoo, H., 2015, Along-strike sequence stratigraphy across the Cretaceous shallow marine to coastal-plain transition, Wasatch Plateau, Utah, U.S.A., Sedimentary Geology, v. 325, p. 59-70.

Garcia, G., Assine, M. L. and Soares, U. M., 2014, Modelagem estratigráfica do intervalo Cenomaniano-Turoniano, formações Açu e Jandaíra, na borda sudoeste da Bacia Potiguar, Boletim de Geociências - Petrobras, v. 22 no. 1, p. $29-50$.

Garcia, X., Julià, J., Nemocón, A. M., and Neukirch, M., 2019, Lithospheric thinning under the Araripe Basin (NE Brazil) from a long-period magnetotelluric survey: Constraints for tectonic inversion, Gondwana Research, v. 68 , p. 174-184, doi:10.1016/j.gr.2018.11.013

Garzione, C. N., Quade, J., DeCelles P. G. and English, N. B., 2000, Predicting paleoelevation of Tibet and the Himalaya from $\delta 18 \mathrm{O}$ vs. altitude gradients in meteoric water across the Nepal Himalaya, Earth and Planetary Science Letters, v. 181 no. 1 , p. $215-229$.

Ghosh, P., Garzione, C. N. and Eilet, J. M., 2006, Rapid Uplift of the Altiplano Revealed Through ${ }^{13} \mathrm{C}-{ }^{18} \mathrm{O}$ Bonds in Paleosol Carbonates, Science, v. 311 no. 5760, p. 511-515.

Gibson, T. G., and Bybell, L. M., 1981, Facies changes in the Hatchetigbee Formation in Alabama-Georgia and the Wilcox-Claiborne Group unconformity, Gulf Coast Association of Geological Societies Transactions, v. 31, p. 301-306. 
Goldhammer, R. K., 1997, Compaction and decompaction algorithms for sedimentary carbonates, Journal of Sedimentary Geology, v. 67 no. 1, p. 26-35.

Gómez, J., Schobbenhaus, C. and Montes, N. E., compilers, 2019, Geological Map of South America 2018, scale 1:5 000 000, Commission for the Geological Map of the World (CGMW), Colombian Geological Survey and Geological Survey of Brazil, Paris, FR.

Gregory, K. M., and C. G. Chase, 1992, Tectonic significance of paleobotanically estimated climate and altitude of the late Eocene erosion surface, Colorado, Geology, v. 20, p. 581-585.

Guillocheau, F., Rouby, D., Robin, C., Helm, C., Rolland, N., De Veslud, C. L. C., and Braun, J., 2012, Quantification and causes of the terrigeneous sediment budget at the scale of a continental margin: A new method applied to the Namibia-South Africa margin, Basin Research, v. 24 no. 1, p. 3-30, doi:10.1111/j.1365-2117.2011.00511.x.

Hack, J. T., 1975, Dynamic equilibrium and landscape evolution: Theories of Landform Development, Publications in Geomorphology, v. 1, p. 87-102.

Hampson, G. J., 2010, Sediment dispersal and quantitative stratigraphic architecture across an ancient shelf, Sedimentology, v. 57, p. 96-141, doi:10.1111/j.1365-3091.2009.01093.x.

Haq, B. U., Hardenbol, J., and Vail, P. R., 1987, The new chronostratigraphic basis of Cenozoic and Mesozoic sea level cycles, Special Publication, Cushman Foundation for Foraminiferal Research, v. 24, p. 7-13.

Haq, B. U., and Al-Qahtani, A. M., 2005, Phanerozoic cycles of sea-level change on the Arabian Platform, GeoArabia, v. 10 no. 2 , p. $127-160$.

Heine, C., Yeo, L. G., and Müller, R. D. (2015). Evaluating global paleoshoreline models for the Cretaceous and Cenozoic, Australian Journal of Earth Sciences, v. 62 no. 3, p. 275-287, doi:10.1080/08120099.2015.1018321.

Heller, P. L., and Paola, C., 1989, The paradox of Lower Cretaceous gravels and the initiation of thrusting in the Sevier orogenic belt, United States Western Interior, Geological Society of America Bulletin, v. 101 no. 6, p. 864-875.

Herman, F., Seward, D., Valla, P. G., Carter, A., Kohn, B., Willett, S. D. and Ehlers, T., 2013, Worldwide acceleration of mountain erosion under a cooling climate, Nature, 504 no. 7480, p. 423-426, doi:10.1038/nature12877.

Hintze, L. and Kowallis, B., 2009, Geologic history of Utah: Brigham Young University Geology Studies Special Publication 9, Brigham Young University, Salt Lake City, UT.

Hoggard, M. J., N. White, and D. Al-Attar, 2016, Global dynamic topography observations reveal limited influence of large-scale mantle flow, Nature Geoscience, v. 9, p. 456.

Holmes, A., 1965, Principles of Physical Geology, London, Nelson, 1288 p.

Immenhauser, A, 2009, Estimating palaeo-water depth from the physical rock record, Earth-Science Reviews, v. 96, p. 107-139, doi:10.1016/j.earscirev.2009.06.003.

Jardim de Sá, E., Matos, R. M. D., Morais Neto, J., Saadi, A., and Pessoa Neto, O., 1999, Epirogenia Cenozóica na Província Borborema: síntese e discussão sobre os modelos de deformação associados, Proceedings of the VII Simpósio Nacional de Estudos Tectônicos, Sociedade Brasileira de Geologia, Lençóis, Brazil, p. 58-61.

Jardim de Sá, E. F., Souza, Z. S., Vasconcelos, P. M., Saadi, A., Galindo, A. C., Lima, M. G., and Oliveira, M. J. R., 2005, Marcos Temporais para a Evolução Cenozóica do Planalto da Borborema, X Simpósio Nacional de Estudos Tectônicos - IV International Symposium on Tectonics - Abstracts, Sociedade Brasileira de Geologia, Curitiba, Brazil, p. 160-162.

Johnson, S. Y., 1992, Phanerozoic evolution of sedimentary basins in the Uinta-Piceance Basin region, northwestern Colorado and northeastern Utah, U. S. Geological Survey Bulletin 1787-FF, US Department of the Interior, US Geological Survey.

Johnson, K. R., Nichols, D. J., and Hartman, J. H., 2002, Hell Creek Formation: a 2001 synthesis, in, Hartman, J. H., Johnson, K. R. and Nichols, D. J. eds. The Hell Creek Formation and the Cretaceous-Tertiary boundary in the northern Great Plains: An integrated continental record of the end of the Cretaceous, Geological Society of America Special Paper 361, Boulder, CO., p. 503-510. 
Kass, M. S., 1999, Prognathodon stadtmani: (Mosasauridae) a new species from the Mancos Shale (Lower Campanian) of western Colorado, Utah Geological Survey Miscellaneous Publication, v. 99 no. 1, p. 275-294.

Keller, G., Adatte, T., Stinnesbeck, W., Luciani, V., Karoui-Yaakoub, N. and Zaghbib-Turki, D., 2002, Paleoecology of the Cretaceous-Tertiary mass extinction in planktonic foraminifera, Palaeogeography, Palaeoclimatology, Palaeoecology, v. 178, p. 257-297.

Kirkland, J. I., 1996, Paleontology of the Greenhorn cylcothem (Cretaceous: late Cenomanian to middle Turonian) at Black Mesa, northeastern Arizona, New Mexico Museum of Natural History and Science Bulletin, v. 9, p. 1-131.

Klöcking, M., White, N. J., Maclennan, J., McKenzie, D., and Fitton, J. G., 2018a, Quantitative Relationships Between Basalt Geochemistry, Shear Wave Velocity, and Asthenospheric Temperature Beneath Western North America, Geochemistry, Geophysics, Geosystems, v. 19 no. 9, p. 3376-3404, doi:10.1029/2018GC007559.

Klöcking, M., Rodríguez Tribaldos, V., Hoggard, M., White, N., Maclennan, J., and Rezende Guimarães, A., 2018b, Linking uplift and volcanism of the Borborema Province, northeast Brazil, in EGU General Assembly Conference Abstracts, v. 20, p. 9966.

Klöcking, M., Hoggard, M., Rodríguez Tribaldos, V., Richards, F. D., Rezende Guimarães, A., Maclennan, J., and White, N., 2020, A tale of two domes: Neogene to recent volcanism and dynamic uplift of northeast Brazil and southwest Africa, Earth and Planetary Science Letters, v. 547, doi:10.1016/j.epsl.2020.116464.

Kominz, M. A., Browning, J. V., Miller, K. G., Sugarman, P. J., Mizintseva, S., and Scotese, C. R., 2008, Late Cretaceous to Miocene sea-level estimates from the New Jersey and Delaware coastal plain coreholes: An error analysis, Basin Research, v. 20 no. 2, p. 211-226, doi: 10.1111/j.1365-2117.2008.00354.x

Laske, G., Masters, G., Ma, Z., and Pasyanos, M., 2013, Update on CRUST1.0-A 1-degree global model of Earth's crust, in Geophysical Research Abstracts, v. 15, p. 2658, Vienna, Austria: EGU General Assembly.

Lambeck, K., Smither, C., and Johnston, P., 1998, Sea-level change, glacial rebound and mantle viscosity for northern Europe: Geophysical Journal International, v. 134 no. 1, p. 102-144.

Liu, S., and Nummedal, D., 2004, Late Cretaceous subsidence in Wyoming: Quantifying the dynamic component: Geology, v. 32 no. 5, p. 397-400.

Liu, L., and Gurnis, M., 2010, Dynamic subsidence and uplift of the Colorado Plateau: Geology, v. 38 no. 7, p. 663-666, doi:10.1130/G30624.1.

Levander, A., Schmandt, B., Miller, M. S., Liu, K., Karlstrom, K. E., Crow, R. S., Lee, C-T. A. and Humphreys, E. D., 2011, Continuing Colorado plateau uplift by delamination-style convective lithospheric downwelling: Nature, v. 472 no. 7344 , p. 461-465, doi:10.1038/nature10001.

Lodhia, B. H., Roberts, G. G., Fraser, A. J., Fishwick, S., Goes, S., and Jarvis, J., 2018, Continental margin subsidence from shallow mantle convection: Example from West Africa: Earth and Planetary Science Letters, v. 481, p. 350-361, doi:10.1016/j.epsl.2017.10.024.

Lovell, B., 2010, A pulse in the planet: regional control of high-frequency changes in relative sea level by mantle convection: Journal of the Geological Society, London, v. 167, p. 637-648, doi:10.1144/0016-76492009-127.

Luz, R. M. N., Julià, J. and do Nascimento, A. F., 2015a, Crustal structure of the eastern Borborema Province, NE Brazil, from the joint inversion of receiver functions and surface wave dispersion: Implications for plateau uplift: Journal of Geophysical Research - Solid Earth, v. 120, p. 3848-3869, doi:10.1002/2015JB011872.

Luz, R. M. N., Julià, J. and do Nascimento, A. F. (2015b). Bulk crustal properties of the Borborema Province, NE Brazil, from P-wave receiver functions: Implications for models of intraplate Cenozoic uplift: Tectonophysics, v. 644, p. 81-91, doi:0.1016/j.tecto.2014.12.017.

Machado Júnior, D. L., Dehira, L. K., Carneiro, C. R., and Almeida, F. F. M., 1990, Reconstruções paleoambientais do Juro-Cretáceo no nordeste Brasileiro: Revista Brasileira de Geociências, v. 19 no. 4, p. 470-485.

Magara, K., 1980, Comparison of Porosity-Depth Relationships of Shale and Sandstone: Journal of Petroleum Geology, v. 3 , no. 2 , p. 175-185, doi:10.1111/j.1747-5457.1980.tb00981.x. 
Magnavita, L. P., Davison, I., and Kusznir, N. J., 1994, Rifting, erosion and uplift history of the Recôncavo-TucanoJatobá Rift, northeast Brazil: Tectonics, v. 13 no. 2, p. 367-388.

Markwick, P. J., 2019, Palaeogeography in exploration: Geological Magazine, v. 156 no. 2, p. 366-407 doi:10.1017/S0016756818000468.

Marques, F. O., Nogueira, F. C. C., Bezerra, F. H. R., and De Castro, D. L., 2014, The Araripe Basin in NE Brazil: An intracontinental graben inverted to a high-standing horst: Tectonophysics, v. 630, p. 251-264, doi:10.1016/j.tecto.2014.05.029.

Martill, D. M., 1988, Preservation of fish in the Cretaceous Santana Formation of Brazil: Palaeontology, v. 31 no. 1, p. $1-18$.

de Matos, R. M. D., 1992, The northeast Brazilian rift system: Tectonics, v. 11 no. 4, p. 766-791, doi:10.1029/91TC03092.

McDonough, K. J. and Cross, T. A., 1991, Late Cretaceous sea level from a paleoshoreline: Journal of Geophysical Research - Solid Earth, v. 96 no. B4, p. 6591-6607, doi:10.1029/91JB00281.

McNab, F., Ball, P. W., Hoggard, M. J., and White, N. J., 2018, Neogene uplift and magmatism of Anatolia: Insights from drainage analysis and basaltic geochemistry: Geochemistry, Geophysics, Geosystems, v. 19 no. 1, p. 175-213, doi:10.1002/2017GC007251.

McQuarrie, N., and Chase, C. G., 2000, Raising the Colorado Plateau; discussion and reply: Geology, v. 28 no. 8 , p. 767-768, doi:10.1130/0091-7613(2000)028<0091:RTCP $>2.0$. CO;2.

Menezes, M. R. F., Morais Neto, J. M., Szatmari, P., and York, D., 2003, Relações cronológicas entre o vulcanismo Macau e a Formação Serra do Martins com base na datação Ar/Ar do plug basáltico "Serrote Preto" (RN, Nordeste do Brasil), IX Simpósio Nacional de Estudos Tectônicos - IIII International Symposium on Tectonics - Annals,Búzios, Brazil, p. 246-249.

Merewether, E. A., and McKinney, K. C., 2015, Composite biostratigraphic outcrop sections for Cretaceous Formations along a south-trending transect from northwestern Montana to northwestern New Mexico, USGS, v. 1258, 20151, 087 .

Miller, K. G., 2005, The Phanerozoic record of global sea-level change: Science, v. 310 no. 5752, p. 1293-1298, doi:10.1126/science.1116412.

Miller, K. G., Mountain, G. S., Wright, J. D., and Browning, J. V., 2011, A 180-million-year record of sea level and ice volume variations from continental margin and deep-sea isotopic records, Oceanography, v. 24 no. 2, p. 40-53.

Mitrovica, J. X., Beaumont, C., and Jarvis, G. T., 1989, Tilting of continental interiors by the dynamical effects of subduction: Tectonics, v. 8 no. 5, p. 1079-1094, doi:10.1029/TC008i005p01079.

Mitrovica, J. X., Milne, G. A., 2002, On the origin of late Holocene sea-level highstands within equatorial ocean basins: Quaternary Science Reviews, v. 21 no. 20, p. 2179-2190, doi:10.1016/S0277-3791(02)00080-X.

Mitrovica, J. X., Austermann, J., Coulson, S., Creveling, J. R., Hoggard, M. J., Jarvis, G. T., and Richards, F. D., 2020, Dynamic Topography and Ice Age Paleoclimate: Annual Review of Earth and Planetary Sciences, v. 48, p. 585-621, doi:10.1146/annurev-earth-082517-010225.

Molnar, P., and P. England, 1990, Late Cenozoic uplift of mountain ranges and global climate change: chicken or egg?: Nature, v. 346 no. 6279 , p. 29-34, doi:10.1038/346029a0.

Morais Neto, J., Hegarty, K. A., Karner, G. D., and Alkmim, F. F. D., 2009, Timing and mechanisms for the generation and modification of the anomalous topography of the Borborema Province, northeastern Brazil: Marine and Petroleum Geology, v. 26 no. 7, p. 1070-1086, doi:10.1016/j.marpetgeo.2008.07.002

Morgan, P., and Swanberg, C. A., 1985, On the Cenozoic uplift and tectonic stability of the Colorado Plateau: Journal of Geodynamics, v. 3 no. (1-2), p. 39-63. 
Morris, M., Fernandes, V. M., and Roberts, G. G., 2020, Extricating dynamic topography from subsidence patterns: Examples from Eastern North America's passive margin: Earth and Planetary Science Letters, v. 530, 115840, doi:10.1016/j.epsl.2019.115840.

Moucha, R., Forte, A. M., Mitrovica,J. X., Rowley, D. B., Quéré, S., Simmons, N. A. and Grand, S. P., 2008a, Dynamic topography and long-term sea-level variations: There is no such thing as a stable continental platform: Earth and Planetary Science Letters, v. 271 no. 1-4, p. 101-108.

Moucha, R., Forte, A. M., Rowley, D. B., Mitrovica, J. X., Simmons, N. A., and Grand, S. P., 2008b, Mantle convection and the recent evolution of the Colorado Plateau and the Rio Grande Rift valley: Geology, v. 36 no. 6, p. 439-442, doi:10.1130/G24577A.1. s

Müller, R. D., Sdrolias, M., Gaina, C., Steinberger, B., and Heine, C., 2008, Long-term sea-level fluctuations driven by ocean basin dynamics: Science, v. 319 no. 5868, p. 1357-1362, doi:10.1126/science.1151540.

Obradovich, J. D., and Cobban, W. A., 1975, A time-scale for the Late Cretaceous of the Western Interior of North America: Geological Association of Canada Special Paper, v. 13, p. 31-54.

Ojeda, H. A. O., 1983, Estrutura e evolução das bacias mesozóicas emersas da margem continental brasileira: Revista Brasileira de Geociências, v. 13 no. 2, p. 71-83.

O'Leary, M. A., Bouaré, M. L., Claeson, K. M., Heilbronn, K., Hill, R. V., McCartney, J., Sessa, J. A., Sissoko, F., Tapanila, L., Wheeler, E., and Roberts, E. M., 2019, Stratigraphy and Paleobiology of the Upper Cretaceous-Lower Paleogene Sediments from the Trans-Saharan Seaway in Mali: Bulletin of the American Museum of Natural History, v. 436, p. 1-183, doi:10.1206/003-0090.436.1.1.

Oliveira, R. G., and Medeiros, W. E., 2012, Evidences of buried loads in the base of the crust of Borborema Plateau (NE Brazil) from Bouguer admittance estimates: Journal of South American Earth Sciences, v. 37, p. 60-76, doi:10.1016/j.jsames.2012.02.004.

Olson, H. C., and Keckie, R. M., 2003, Foraminifera as proxies for sea-level change on siliciclastic margins: SEPM Special Publication, v. 74, p. 5-19.

Palmer, K. V. and Brann, D. C., 1965, Catalogue of the Paleocene and Eocene mollusca of the southern and eastern United States. Part 1. Pelecypoda-Amphineura-Peteropoda-Scaphopoda and Cephalopoda: Bulletins of American Paleontology, v. 48, p. 1-471.

Pedoja, K., Husson, L., Johnson, M. E., Melnick, D., Witt, C., Pochat, S., Nexer, M., Delcaillau, B., Pinegina, T., Poprawski, Y. and Authemayou, C., 2014, Coastal staircase sequences reflecting sea-level oscillations and tectonic uplift during the Quaternary and Neogene: Earth-Science Reviews, v. 132, p. 13-38, doi:10.1016/j.earscirev.2014.01.007.

Peulvast, J., and Bétard, F., 2015, A history of basin inversion, scarp retreat and shallow denudation: The Araripe basin as a keystone for understanding tong-term landscape evolution in NE Brazil: Geomorphology, v. 233, p. 20-40, doi:10.1016/j.geomorph.2014.10.009

Pereira, P. A., Cassab, R. C. T., and Barreto, A. M. F., 2016, Cassiopidae gastropods, influence of Tethys Sea of the Romualdo Formation (Aptian-Albian), Araripe Basin, Brazil: Journal of South American Earth Sciences, v. 70, p. $211-223$.

Perrigo, A., Hoorn, C. and Antonelli, A., 2019, Why mountains matter for biodiversity: Journal of Biogeography, v. 47 no. 2, p. 315-325.

Pessoa Neto, O. C., Soares, U. M., Silva, J. G. F., Roesner, E. H., Florencio, C. P., and Souza, C. A. V., 2007, Bacia Potiguar: Boletim de Geociências - Petrobras, v. 15 no. 2, p. 357-369.

Plint, A. G., Tyagi, A., Hay, M. J., Varban, B. L., Zhang, H., and Roca, X., 2009, Clinoforms, paleobathymetry, and mud dispersal across the Western Canada Cretaceous foreland basin: evidence from the Cenomanian Dunvegan Formation and contiguous strata: Journal of Sedimentary Research, v. 79 no. 3, p. 144-161, doi:10.2110/jsr.2009.020.

Priestley, K., and McKenzie, D., 2013, The relationship between shear wave velocity, temperature, attenuation and viscosity in the shallow part of the mantle: Earth and Planetary Science Letters, v. 381, p. 78-91, doi:10.1016/j.epsl.2013.08.022. 
Prado, L. A. C., Pereira, P. A., Sales, A. M. F., and Barreto, A. M. F., 2016, Tafonomia dos Invertebrados do Sítio Canastra, Formação Romualdo, Cretáceo Inferior, Bacia do Araripe, Araripina, Pernambuco, Brasil: Anuário do Instituto de Geociências, v. 39 no. 2, p. 77-87.

Raymo, M. E., and Ruddiman, W. F., 1992, Tectonic forcing of late Cenozoic climate: Nature, v. 359 no. 6391 , p. 117-122.

Reed, J. C., Wheeler, J. O., Tucholke, B. E., Card, K. D., Davidson, A., Hoffman, P. F., Okulitch, A. V., Palmer, A. R., Sanford, B. V., Williams, G. K., Williams, H., Dixon, J., Embry, A. F., Holcombe, T. L., Laine, E. P., Mountain, G. S., Popenoe, P., and Wiley, T., 2005, Geologic map of North America: Geological Society of America, Continent-Scale Map 001, scale 1:5,000,000, Geological Society of America, Boulder-CO, USA.

Reilinger, R., McClusky, S., Paradissis, D., Ergintav, S., and Vernant, P., 2010, Geodetic constraints on the tectonic evolution of the Aegean region and strain accumulation along the Hellenic subduction zone: Tectonophysics, v. 488 no. 1-4, p. 22-30, doi:10.1016/j.tecto.2009.05.027.

Roberts, L. N., and Kirschbaum, M. A., 1995, Paleogeography of the Late Cretaceous of the Western Interior of middle North America-Coal distribution and sediment accumulation: U.S. Geological Survey Professional Paper 1561, 115 p.

Roberts, G. G., White, N. J., Martin-Brandis, G. L., and Crosby, A. G., 2012, An uplift history of the Colorado Plateau and its surroundings from inverse modeling of longitudinal river profiles: Tectonics, v. 31 no. 4 , doi:10.1029/2012TC003107.

Rodrigues, R., 1995, A geoquimica orgânica da Bacia do Parnaíba, Doctoral Thesis, Universidade Federal do Rio Grande do Sul - UFRGS, 225 pp.

Rodríguez Tribaldos, V., White, N. J., Roberts, G. G., and Hoggard, M. J., 2017, Spatial and temporal uplift history of South America from calibrated drainage analysis: Geochemistry, Geophysics, Geosystems, v. 18 no. 6, p. 2321-2353, doi:10.1002/2017GC006909.

Rossetti, D. F., and Santos Jr., A. E. A., 2004, Facies architecture in a tectonically-influenced estuarine incised valley fill of Miocene age, northern Brazil: Journal of South American Earth Sciences, v. 17, p. 267-284.

Rossetti, D. F., Bezerra, F. H. R., and Dominguez, J. M. L., 2013, Late Oligocene-Miocene transgressions along the equatorial and eastern margins of Brazil: Earth-Science Reviews, v. 123, p. 87-112, doi:10.1016/j.earscirev.2013.04.005.

Rowley, D. B., 2013, Sea level: Earth's dominant elevation-Implications for duration and magnitudes of sea level variations: The Journal of Geology, v. 121 no. 5, p. 445-454, doi:10.1086/671392.

Sahagian, D., 1987, Epeirogeny and eustatic sea level changes as inferred from Cretaceous shoreline deposits: Applications to the central and western United States: Journal of Geophysical Research - Solid Earth, v. 92, p. 4895-4904, doi:10.1029/JB092iB06p04895.

Sahagian, D., Pinous, O., Olferiev, A., and Zakharov, V., 1996, Eustatic curve for the Middle Jurassic-Cretaceous based on Russian Platform and Siberian stratigraphy: Zonal resolution: AAPG bulletin, v. 80 no. 9, p 1433-1458.

Sahagian, D., and Proussevitch, A., 2007, Paleoelevation measurement on the basis of vesicular basalts: Reviews in Mineralogy and Geochemistry, v. 66 no. 1, p. 195-213, doi:10.2138/rmg.2007.66.8.

Sclater, J. G. and Christie, P. A. F., 1980, Continental stretching: An explanation for the post-Mid-Cretaceous subsidence of the Central North Sea Basin: Journal of Geophysical Research, v. 85 no. B7, p. 3711-3739.

Scotese, C. R., and Golonka, J., 1992, Paleogeographic atlas: Paleomap Project, Arlington, Texas, Department of Geology, University of Texas at Arlington.

Sloss, L. L., 1963, Sequences in the cratonic interior of North America: Geological Society of America Bulletin, v. 74 no. 2, p. 93-114.

Smith, A. G., Smith, D. G. and Funnell, B. M., 1994, Atlas of Mesozoic and Cenozoic Coastlines, 99 pp., Cambridge University Press. 
Stephenson, S. N., Roberts, G. G., Hoggard, M. J., and Whittaker, A. C., 2014, A Cenozoic uplift history of Mexico and its surroundings from longitudinal river profiles: Geochemistry, Geophysics, Geosystems, v. 15 no. 12, p. 4734-4758, doi:10.1002/2014GC005425.

Stewart, D. B. and Lockhart, W. L., 2006, An Overview of the Hudson Bay Marine Ecosystem: Canadian Technical Report of Fisheries and Aquatic Sciences, v. 2586.

Stucky de Quay, G., Roberts, G. G., Rood, D. H. and Fernandes, V. M., 2019, Holocene uplift and rapid fluvial erosion of Iceland: A record of post-glacial landscape evolution: Earth and Planetary Science Letters, v. 505, p. 118-130, doi:10.1016/j.epsl.2018.10.026.

Suess, E., 1906, The Face of the Earth, Clarendon Press, Oxford, 556 p.

Sulser, H. Garcia-Ramso, D. Kursteiner, P., and Menkveld-Gfeller, U., 2010, Taxonomy and palaeoecology of brachiopods from the South-Helvetic zone of the Faneren region (Lutetian, Eocene, NE Switzerland): Swiss Journal of Geosciences, v. 103, p. 257-272.

Tapanila, L., Roberts, E., Bouaré, M. L., Sissoko, F., and O'Leary, M. A., 2008, Phosphate taxonomy of bone and comprolite conglomerates: a case study from the Eocene of Mali, NW Africa: Palaios, v. 23 139-152.

Tintant, H., Lang, J., Moussa, B., Alzouma, K., and Dikouma, M., 2001, Nautiles Paléocènes du Niger: Geobios, v. 34 , p. $629-656$.

USGS Uinta-Piceance Assessment (UUPA) Team, 2003, Petroleum systems and geologic assessment of oil and gas in the Uinta-Piceance Province, Utah and Colorado, 69-B, US Geological Survey.

Ussami, N., Molina, E. C., Medeiros, W. E., 1999, Novos vínculos sobre a evolução térmica da margem continental leste do Brasil: VII Simpósio Nacional de Estudos Tectônicos, Lençóis, Annals, v. S3, p. 20-23.

Vail, P. R., Mitchum, R. M. and Thompson, S., 1977, Relative Changes of Sea Level from Coastal Onlap; in Seismic Stratigraphy-Applications to Hydrocarbon Exploration, Ed: Payton, C. E., AAPG Memoir, v. 26, p. 63-81.

van Wijk, J. W., Baldridge, W. S., van Hunen, J., Goes, S., Aster, R., Coblentz, D. D., Grand, S. P. and Ni, J., 2010, Small-scale convection at the edge of the Colorado Plateau: Implications for topography, magmatism, and evolution of Proterozoic lithosphere: Geology, v. 38, p. 611-614, doi:10.1130/G31031.1.

Walford, H. L., and White, N. J., 2005, Constraining uplift and denudation of west African continental margin by inversion of stacking velocity data: Journal of Geophysical Research - Solid Earth, v. 110 no. B4, doi:10.1029/2003JB002893.

Watts, A. B., 2001, Isostasy and Flexure of the Lithosphere, Cambridge University Press, Cambridge, UK.

Watts, A. B. and Steckler, M. S., 1979, Subsidence and Eustasy at the Continental Margin of Eastern North America, in Deep Drilling Results in the Atlantic Ocean: Continental Margins and Paleoenvironment; Eds: Talwani, M., Hay, W., Ryan, W. B. F. v. 3, Maurice Ewing Series, doi:10.1029/ME003p0218.

White, N., and McKenzie, D., 1988, Formation of the "steer's head" geometry of sedimentary basins by differential stretching of the crust and mantle: Geology, v. 16 no. 3, p. 250-253, doi:10.1130/00917613(1988)016<0250:FOTSSH >2.3.CO;2.

Wyllie, M. R. J., Gregory, A. R. and Gardner, L. W., 1956, Elastic wave velocities in heterogeneous and porous media: Geophysics, v. 21 no. 1, p. 41-70, doi:10.1190/1.1438217.

Ziegler, A., Rowley, D., Lottes, A., Sahagian, D., Hulver, M. and Gierlowski, T., 1985, Paleogeographic interpretation: with an example from the mid-Cretaceous: Annual Reviews of Earth and Planetary Science, v. 13, p. 385-425, doi:10.1146/annurev.earth.13.1.385. 